\title{
A Review on the Application of Zeolites and Mesoporous Silica Materials in the Removal of Non-Steroidal Anti-Inflammatory Drugs and Antibiotics from Water
}

\author{
Agnieszka Grela ${ }^{1,2, *(\mathbb{C},}$ Joanna Kuc 2,3(1) and Tomasz Bajda ${ }^{2}$ (1) \\ 1 Faculty of Environmental and Power Engineering, The Cracow University of Technology, \\ 30-155 Cracow, Poland \\ 2 Faculty of Geology, Geophysics and Environmental Protection, AGH University of Science and Technology, \\ 30-059 Cracow, Poland; jkuc@agh.edu.pl (J.K.); bajda@agh.edu.pl (T.B.) \\ 3 Faculty of Chemical Engineering and Technology, The Cracow University of Technology, \\ 30-155 Cracow, Poland \\ * Correspondence: agrela@agh.edu.pl; Tel.: +48-12-617-56-30
}

\section{check for}

updates

Citation: Grela, A.; Kuc, J.; Bajda, T. A Review on the Application of Zeolites and Mesoporous Silica Materials in the Removal of Non-Steroidal Anti-Inflammatory Drugs and Antibiotics from Water. Materials 2021, 14, 4994. https:// doi.org/10.3390/ma14174994

Academic Editors: Bruno De Gennaro, Barbara Liguori, Abner Colella and Domenico Caputo

Received: 14 July 2021

Accepted: 27 August 2021

Published: 1 September 2021

Publisher's Note: MDPI stays neutral with regard to jurisdictional claims in published maps and institutional affiliations.

Copyright: (c) 2021 by the authors. Licensee MDPI, Basel, Switzerland. This article is an open access article distributed under the terms and conditions of the Creative Commons Attribution (CC BY) license (https:// creativecommons.org/licenses/by/ $4.0 /)$.

\begin{abstract}
Zeolites and mesoporous silica materials are effective adsorbents that can be useful for the removal of various pharmaceuticals including non-steroidal anti-inflammatory drugs and antibiotics from low-quality water. This paper summarizes the properties and basic characteristics of zeolites and mesoporous silica materials and reviews the recent studies on the efficacy of the adsorption of selected non-steroidal medicinal products and antibiotics by these adsorbents to assess the potential opportunities and challenges of using them in water treatment. It was found that the adsorption capacity of sorbents with high silica content is related to their surface hydrophobicity (hydrophilicity) and structural features, such as micropore volume and pore size, as well as the properties of the studied medicinal products. This review can be of help to scientists to develop an effective strategy for reducing the amount of these two groups of pharmaceuticals in wastewater.
\end{abstract}

Keywords: zeolites; mesoporous sorbents; wastewater purification; drug analysis

\section{Introduction}

Pharmaceuticals are substances with a high biological activity, which are introduced into the body in a strictly defined dose to achieve a desired (therapeutic or preventive) effect. They are exposed to the environment in many ways, the most important being excretion by humans and animals and inappropriate disposal of drugs. These compounds are excreted from the body in the form of parent compounds or as metabolites formed in the first and second phase of biotransformation [1-3]. Many pharmaceutically active compounds were already detected in water in the 1980s. Bush (1997) grouped these therapeutic substances into the following classes: (a) anti-inflammatory agents and analgesics, (b) antibiotics, (c) antiepileptics, (d) antidepressants, (e) lipid-lowering agents, (f) antihistamines, (g) $\beta$ blockers, and (h) other substances [3,4].

Pharmaceuticals that are most frequently detected, including antibiotics, anti-inflammatory drugs, and analgesics, have become a growing environmental concern worldwide $[5,6]$. They occur mainly in the aquatic environments, such as surface and underground waters, water reservoirs, effluents and influents of sewage treatment plants, and drinking water [7-13]. Medicines are found in trace concentrations up to $100 \mu \mathrm{g} \mathrm{L}^{-1}$ in wastewater resulting from drug production [14]. Drugs are found in the environment because these pollutants cannot be completely removed in sewage treatment plants [15], and thus persist without undergoing degradation [16]. Incomplete elimination of pharmaceuticals was also observed in drinking water treatment plants $[17,18]$. This paper focuses on two groups of pharmaceuticals - non-steroidal anti-inflammatory drugs (NSAIDs) and antibioticsas they are the most widely used medicinal products worldwide. NSAIDs (diclofenac, 
ibuprofen, ketoprofen, and naproxen) were chosen owing to their large-scale use and widespread distribution in surface waters and wastewater, which is confirmed by numerous scientific studies [19-21]. In turn, the antibiotics discussed in this article (erythromycin, sulfamethoxazole, tetracycline, and trimethoprim) were selected as they are included in the World Health Organization's List of Essential Medicines [22] and are also used widely as antimicrobial substances against bacteria $[20,23,24]$. Of the NSAIDs of interest, only ibuprofen is on the WHO list. Figure 1a-d presents the concentrations of selected drugs from the group of NSAIDs and antibiotics found in the aquatic environment based on data from the analyzed studies.
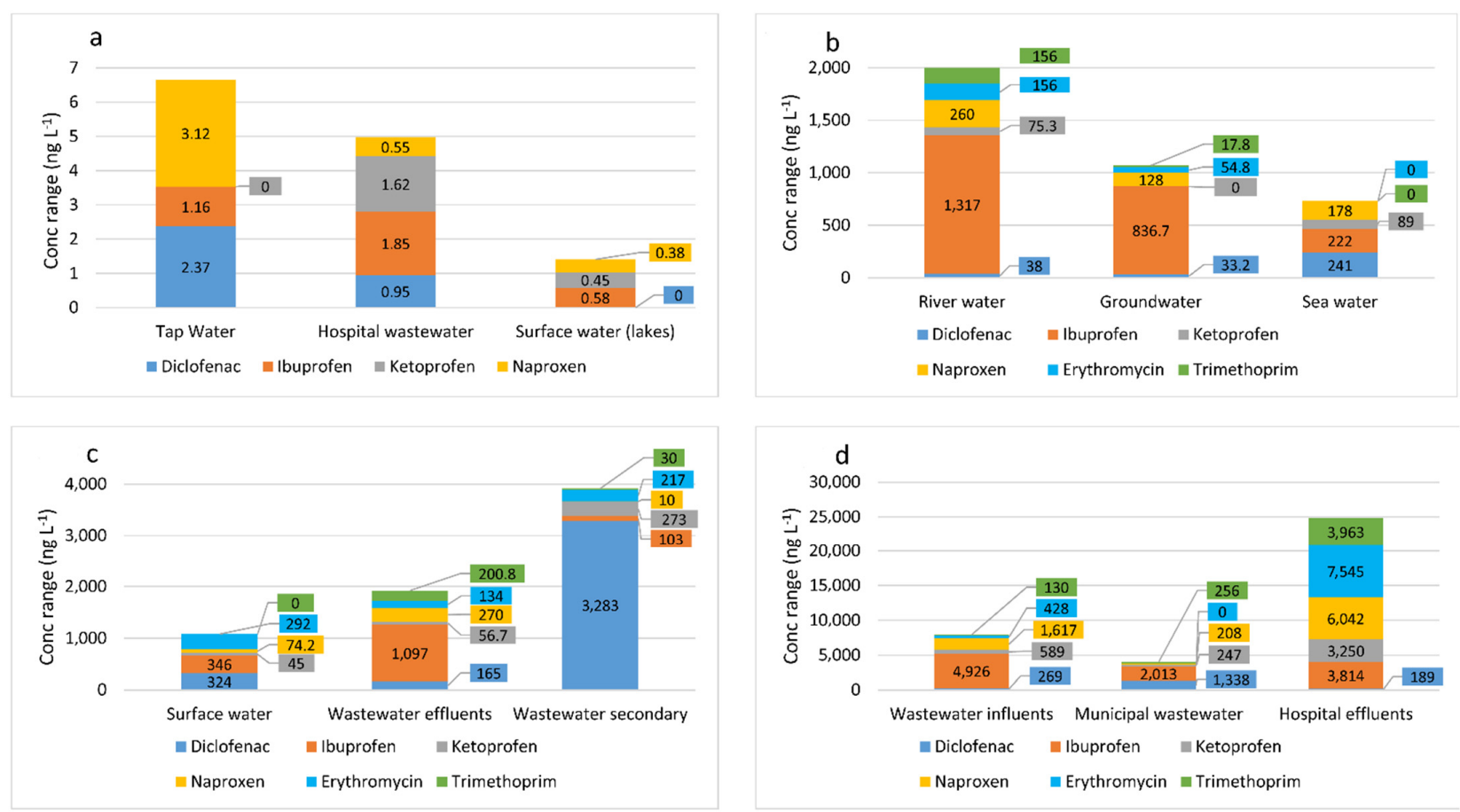

Figure 1. Concentrations of some pharmaceuticals (antibiotics, anti-inflammatory drugs, and analgesics) recorded in the world in selected water types: (a) tap water [25], hospital wastewater, and surface water (lakes) [26]; (b) river water, groundwater [27], and seawater [28]; (c) surface water [29], wastewater effluents, and wastewater secondary [27,30]; and (d) wastewater influents [30], municipal wastewater [29], and hospital effluents [30].

Based on the data from Figure $1 \mathrm{a}-\mathrm{d}$, it can be stated that antibiotic concentrations were highest in hospital effluents, wastewater effluents, and river water. In three types of water (tap water, hospital wastewater, surface water (lakes)) presented in Figure 1a, erythromycin and trimethoprim were not detected. The highest concentrations of diclofenac, ibuprofen, and ketoprofen were found in wastewater influents, municipal wastewater, and hospital effluents. Thus, it can be concluded that the drug concentrations in different types of waters and wastewater are found in the following order: hospital effluents $>$ wastewater influents $>$ municipal wastewater $>$ secondary wastewater $>$ river water $>$ wastewater effluents $>$ groundwater $>$ surface water $>$ seawater $>$ tap water $>$ hospital wastewater $>$ surface water (lakes). Owing to human activity, pharmaceuticals are detected in various types of water and wastewater on each continent, including the North Scandinavian water environment [31]. The strategy for their removal can be the same everywhere, as long as the concentrations are at a similar level. The most easily removable drugs are mainly those belonging to the group of non-steroidal analgesics and anti-inflammatory drugs, including ibuprofen, ketoprofen, and naproxen. On the other hand, the elimination of pharmaceuticals such as diclofenac from wastewater is difficult.

Pharmaceuticals are chemically stable. However, owing to physicochemical and biotic factors [32], they undergo biodegradation, conjugation, deconstruction, and sorption. 
Therefore, the knowledge of these processes is necessary to predict the environmental fate of medicinal substances [13]. The high stability of drugs is related to their relatively high durability under environmental conditions. In contrast, some pharmaceutical metabolites resulting from oxidation, reduction, and/or hydrolysis are more susceptible to further transformations, and thus are less stable in the aquatic environment [33]. The transformations of pharmaceuticals taking place in the aquatic environment are not thoroughly studied so far [34-36]. Pharmaceuticals undergo many reactions and changes, the first of which dilutes the drugs when they reach the surface water and water reservoirs [37], while chemical reactions may partially or completely change the original pharmaceuticals (parent compounds) [1]. The products resulting from the transformation of pharmaceutical compounds are sometimes more stable than the parent compounds and may be more or less toxic. Moreover, pharmaceuticals may undergo biotic (aerobic and anaerobic) and abiotic (chemical) reactions in the environment $[15,38]$. Most often, pharmaceuticals are trapped in sewage sludge, but their original molecular structures are preserved. This is generally observed in the case of lipophilic and difficult-to-degrade substances. Pharmaceuticals also possibly transform into hydrophilic compounds, which remain stable. Such hydrophilic products pass through sewage treatment plants and reach the flowing surface waters (rivers) and still surface waters (water reservoirs and lakes) [5]. It has been shown that pharmaceuticals exhibit a very wide range of removal rates without any logical scheme, even if they belong to the same therapeutic groups [39]. Figure 2 presents the approximate nonmetabolized fractions of selected pharmaceuticals from the NSAID group and that of antibiotics entering wastewater after ingestion and human metabolism. The $x$-axis excretion percentage represents unmetabolized or partially metabolized pharmaceuticals that are eliminated as the original active ingredient.

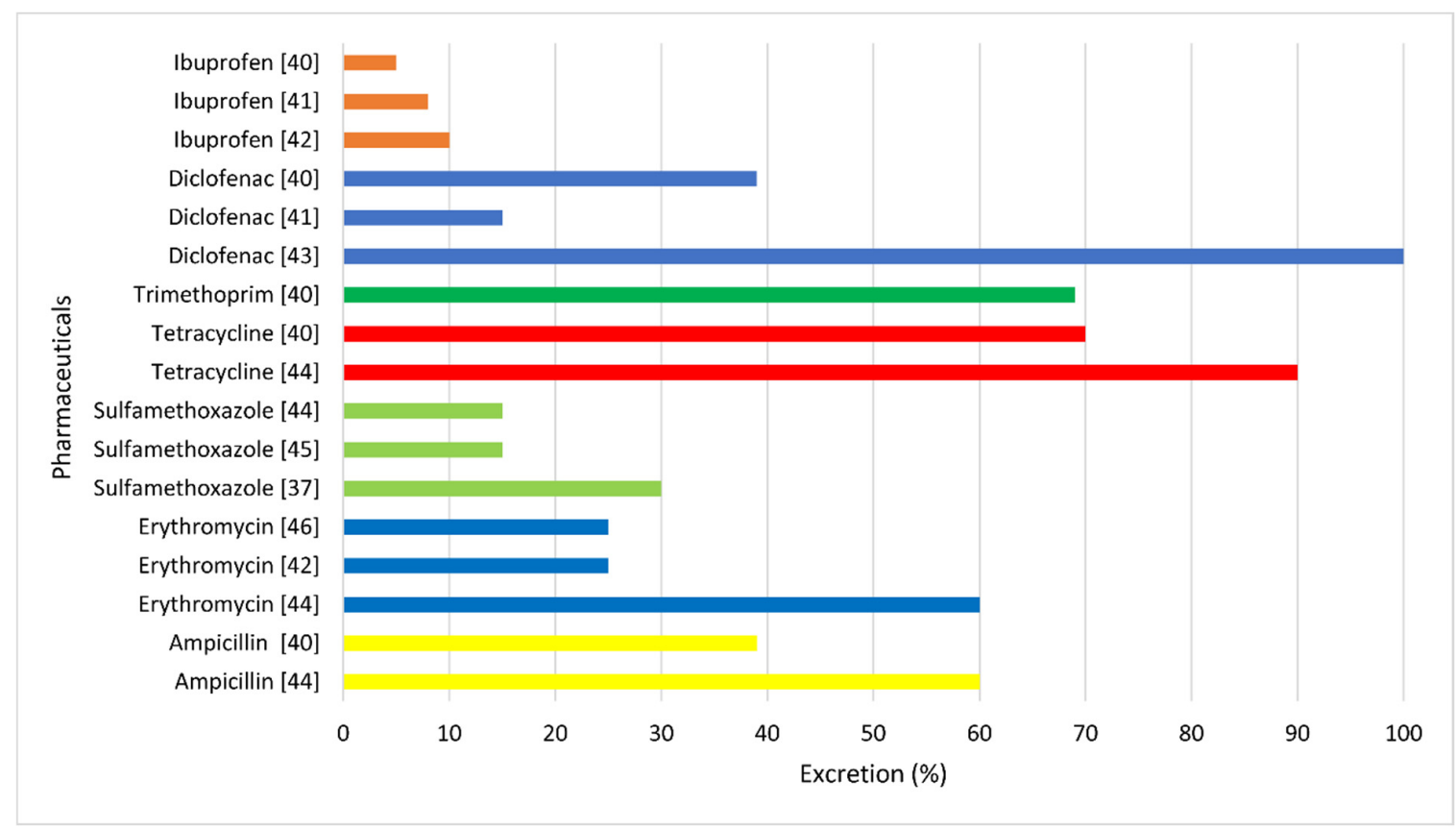

Figure 2. Typical pharmaceuticals and their approximate nonmetabolized fractions entering sewage after being ingested and subjected to human metabolism: ibuprofen [40-42]; diclofenac [40,41,43]; trimethoprim [40]; tetracycline [40,44]; sulfamethoxazole [37,44,45]; erythromycin [42,46]; and amplicillin [40,44].

Pharmaceuticals enter the environment mainly by water transport and further spread into the environment through the food chain [7]. The side effects of these substances are still unknown and have not been tested. Pharmaceuticals can affect aquatic ecosystems, but the extent of this damage is not clear $[5,47]$. Some studies have already reported that these compounds pose both acute and chronic threats to flora and fauna. It has been proven that 
diclofenac has a negative effect on vultures, causing a decline in their population [48]. In turn, Schwaiger et al. [49] and Triebskorn et al. [50] indicated that exposure of rainbow trout to diclofenac results in damage to internal organs. Sulfamethaxazole has also been shown to affect the germination of rice and oats [51].

Because of the above-described consequences, it is necessary to optimize and improve the technologies currently used for the treatment of wastewater and surface water in order to eliminate pharmaceutical residues from them. Because the biological and physical removal efficiency of these residues is not very high, there is a need to search for other more effective cleaning methods. Chemical (e.g., ozonation and oxidation) and physicochemical processes (e.g., adsorption, membrane filtration, and coagulation) are commonly used for the removal of medicines from aqueous solutions [52-54]. Some of the pharmaceutical substances in the suspension go to both primary and secondary sediments. Among the proposed physicochemical processes, adsorption is the most preferred method for removing pharmaceutical residues [55], which works based on the principle of remediation [3]. The advantages of adsorption are that it allows obtaining high-quality treated wastewater, it is easy and cheap to operate, and it does not result in the production of undesirable byproducts $[56,57]$. It can be used for the treatment of various types of water and wastewater, including those with a high content of organic compounds, which cannot be removed by other methods [58] Adsorption of drugs with the use of porous materials, mainly activated carbon, is known as one of the most effective processes for removing these groups of pharmaceuticals, and is thus widely used. Powdered active carbon is often used in adsorption processes $[59,60]$. It contains numerous pores of different sizes and has different functional groups on its surface. However, its disadvantage is the difficulty associated with the regeneration of the used adsorbent and the low-selective adsorption of organic adsorbents, especially at low concentrations. Activated charcoal adsorbs a wide spectrum of medicines, especially hydrophobic compounds, owing to its well-developed pore structure, large surface area, and high degree of fragmentation. On the other hand, hydrophilic drugs are inefficiently removed $[17,18,61]$. A disadvantage encountered with the use of activated charcoal is that the working capacity of the material is significantly reduced if natural organic matter is present, as well as regeneration of the used adsorbent. Regenerative processes significantly affect the pore structure and chemical properties of functional groups in activated carbon, thereby reducing their adsorption efficiency in relation to the removed pharmaceuticals. Thermal regeneration of activated carbon can also cause carbon losses of up to $10 \%$ of its mass, which results in the need to purchase new activated carbon. As an alternative, zeolites and mesoporous silica materials can be used. These are characterized by the need for shorter contact time, lower desorption percentage, and better structural stability (which allows regeneration at high temperature) compared with activated carbon, all of which justify their use. This paper presents the general characteristics of zeolites and mesoporous silica materials and an authoritative review of data from research publications, which have not been discussed before in other studies. While individual publications contain results describing the removal efficiency of a selected pharmaceutical (belonging to one of the two groups analyzed), there is no study providing a comparative summary of removal efficiencies and conditions of the experiments conducted for several compounds from a given group and several zeolite sorbents or mesoporous materials. Therefore, efforts have been made to include in this paper the data on the efficiency of zeolites and mesoporous materials to remove the two most common groups of pharmaceuticalsantibiotics and non-steroid pharmaceuticals-from water. The paper reviews the literature on the physicochemical properties of selected zeolites (natural, synthetic, and high silica) and mesoporous silica materials-Mobil Composition of Matter (MCM-41) and Santa Barbara Amorphous (SBA-15) - and their relation to the adsorption of selected antibiotics and non-steroid pharmaceuticals. The zeolites and mesoporous silica materials described in this paper were chosen for this review because of their high availability in the market and their proven effectiveness in removing antibiotics and non-steroidal drugs from aqueous solutions. Zeolites have been shown to have the potential to be successfully used for the 
adsorption of sulfamethoxazole from water [62]. The adsorption efficiency of zeolites and mesoporous silica materials was characterized taking into account their properties and the diversity of the two analyzed groups of drugs. The paper also discusses the potential possibilities and challenges related to the use of zeolites and mesoporous silica materials in water treatment. The review serves two purposes. Firstly, it allows determining the sorption capacity (described in the literature of zeolites and two mesoporous silica materials) of MCM-41 and SBA-15 in relation to the drugs dissolved in water. Additionally, it can be used to analyze their effectiveness of drug removal and potential use in wastewater treatment and groundwater remediation. Secondly, it allows determining the structural features of the analyzed adsorbent materials, which influence their adsorption of drugs from aqueous solutions. All the collected information may be of help to select materials for water treatment in the future.

\section{Physicochemical Properties of Zeolites and Mesoporous Silica Materials}

\subsection{Zeolites}

The Swedish mineralogist F. Crondtedt used the name zeolite for the first time in 1756. While analyzing the newly discovered mineral, he noticed that it was losing water when heated. In Greek, the word zeolite means "boiling stone" [63]. During the time of their discovery, zeolites were considered as a separate group of minerals [64]. They are defined as tectosilicates, which are inorganic polymers having a three-dimensional structure, and are made up of $\mathrm{SiO}_{4}$ tetraeders, some of which can be replaced by $\mathrm{AlO}_{4}$ [65-67]. A characteristic feature of zeolites is the crystalline structure voids in the form of chambers and channels [68]. The size of zeolites ranges from 3 to $30 \AA$ [69].

Depending on the proportion of silica and aluminium ( $\mathrm{Si} / \mathrm{Al}$ ratio), the properties of zeolites can vary. High-silicon zeolites with a high Si / Al ratio of up to several thousands are produced industrially $[70,71]$. The hydrophobicity of these zeolites is a beneficial property that facilitates the adsorption of pharmaceuticals from aqueous solutions [72].

The structural features of high-silica zeolites are determined mainly by their framework. A framework type represents the unique channel and frame structure and has the greatest impact on the effectiveness of pharmaceutical adsorption. Mordenite (MOR), faujasite (FAU), and MFI are the type of zeolites selected for this review because they are the most commercially available and have already been tested for the removal of antibiotics and non-steroidal drugs from aqueous solutions. Their structural characteristics are summarized in Table 1.

Table 1. Key properties of three commonly used frameworks of zeolites.

\begin{tabular}{|c|c|c|c|c|c|}
\hline \multirow[t]{2}{*}{ Frame-Work Type } & \multicolumn{2}{|c|}{$\begin{array}{c}\text { Ring Number and Pore } \\
\text { Opening Size } \\
{[73]}\end{array}$} & \multirow{2}{*}{$\begin{array}{c}\text { Framework Density } \\
{[73]}\end{array}$} & \multirow{2}{*}{$\begin{array}{c}\text { Accessible Area } \\
\text { Maximum } \\
{[74]}\end{array}$} & \multirow{2}{*}{$\begin{array}{c}\text { Maximum Diameter } \\
\text { of a Sphere } \\
{[74]}\end{array}$} \\
\hline & $(\AA ̊ \AA ̊)$ & $(\AA \times \AA)$ & & & \\
\hline FAU & $\begin{array}{c}12 \text { ring } \\
7.4 \times 7.4\end{array}$ & - & 12.7 & 1211.42 & 11.24 \\
\hline MOR & $\begin{array}{c}12 \text { ring } \\
6.5 \times 7.4 \\
\end{array}$ & $\begin{array}{c}8 \text { ring } \\
2.6 \times 5.7\end{array}$ & 17.2 & 1010.22 & 6.70 \\
\hline MFI & $\begin{array}{c}10 \text { ring } \\
5.1 \times 5.5 \\
\end{array}$ & $\begin{array}{c}10 \text { ring } \\
5.3 \times 5.6 \\
\end{array}$ & 17.9 & 834.41 & 6.36 \\
\hline
\end{tabular}

All the selected framework types are characterized by a large surface area (from 834 to $1211 \mathrm{~m}^{2} \mathrm{~g}^{-1}$ ) for adsorption. The skeleton density of zeolites is related to their pore volume-zeolites with a lower skeleton density have a larger pore volume [75]. The pore volume of zeolites, which is inversely proportional to skeletal structure density, increases in the following order: FAU > MOR > MFI (Table 1). 
Zeolites can also be divided according to their origin into two groups: natural and synthetic. The changes and geological processes taking place in the rocks under hydrothermal conditions favor the formation of natural zeolites. Zeolite deposits occurring in the form of geological deposits, which are profitable for extraction and processing, are found only for some types, such as clinoptilolite, MOR, philipsite, and chabasite. Synthetic zeolites can also be obtained by chemical synthesis. The synthesis of these zeolites is usually carried out under hydrothermal conditions in an alkaline environment [76]. Clay minerals, minerals from the silica group, and by-products of coal combustion (e.g., fly ash) can be used as raw materials for chemical synthesis. The synthesis process changes the chemical and mineral composition and structure of the raw material, consequently giving rise to a zeolite material with new physicochemical properties [77]. Table 2 presents a summary of publications describing the synthesis of selected synthetic zeolites (Na-A, Na-P1, and $\mathrm{Na}-\mathrm{X}$ ) from fly ashes.

Table 2. Selected publications on the synthesis of synthetic zeolites $\mathrm{Na}-\mathrm{A}, \mathrm{Na}-\mathrm{P} 1$, and $\mathrm{Na}-\mathrm{X}$ from fly ashes.

\begin{tabular}{|c|c|c|c|c|c|}
\hline \multirow{2}{*}{ Type of Zeolite } & \multicolumn{3}{|c|}{ Conditions of Synthesis } & \multirow{2}{*}{ NaOH/Fly Ash Ratio } & \multirow{2}{*}{ Reference } \\
\hline & $\mathrm{NaOH}[\mathrm{M}]$ & $\mathrm{T}\left[{ }^{\circ} \mathrm{C}\right]$ & $\mathbf{t}[\mathbf{h}]$ & & \\
\hline \multirow{4}{*}{$\mathrm{Na}-\mathrm{A}$} & $0.5-3.5$ & 60 & $10-48$ & $0.5-3.5$ & [78] \\
\hline & 2.0 & 100 & 2 & 0.8 & [79] \\
\hline & 2.2 & 85 & 12 & 0.23 & [80] \\
\hline & $2.0-5.0$ & $100-150$ & $0.5-6$ & $0.5-1.6$ & [81] \\
\hline \multirow{11}{*}{$\mathrm{Na}-\mathrm{P} 1$} & $2.8-5.0$ & 25 & 48 & $0.28-0.5$ & [82] \\
\hline & 2.0 & $90-150$ & 12 & - & [83] \\
\hline & 3.0 & 103 & 12 & 0.5 & [84] \\
\hline & $1.0-3.0$ & 90 & 21 & $0.4-1.2$ & [85] \\
\hline & $0.5-5.0$ & $150-200$ & $3-48$ & - & [86] \\
\hline & 3.0 & 125 & 8 & - & [87] \\
\hline & $0.4-0.5$ & 120 & $3-24$ & $0.08-0.64$ & [88] \\
\hline & 3.0 & 125 & 9 & 0.96 & [86] \\
\hline & 1.16 & $80-320$ & 6 & 0.28 & [89] \\
\hline & 1.0 & 105 & 24 & 0.8 & [90] \\
\hline & - & 100 & $12-48$ & 1.0 & [91] \\
\hline \multirow{4}{*}{$\mathrm{Na}-\mathrm{X}$} & 3.0 & 90 & $24-72$ & 0.3 & [92] \\
\hline & 3.0 & 75 & 24 & 2.4 & [90] \\
\hline & - & 10 & 120 & - & [93] \\
\hline & 3.0 & 75 & 24 & 0.33 & [65] \\
\hline
\end{tabular}

The resulting zeolite materials should be filtered, rinsed from $\mathrm{NaOH}$, and dried at about $100{ }^{\circ} \mathrm{C}$ for several hours [94]. An advantage of the synthesis of zeolites under laboratory conditions over the natural formation is that the obtained material lasts much shorter [95]. Hence, synthetic zeolites are often used in practice as opposed to natural ones [96]. A cost-effective structural modification is performed before natural zeolites are applied in industries. Moreover, synthetic zeolites are characterized by better texture and adsorption properties compared with natural zeolites. This is because the conditions of the synthesis process can be controlled to obtain zeolite materials with the optimal structure for selected applications. Chemical synthesis of zeolites involves great cost; therefore, the substrates used for synthesis should be cheap mineral or waste materials [97]. Furthermore, zeolites obtained from the conversion of fly ash are characterized by a low production cost, durability, chemical inertia, nonflammability, and developed specific surface area, which are important features found in top-class adsorbents. Another area where zeolites can be applied is to remove pharmaceuticals from water $[98,99]$. The following subsections present the role and effectiveness of selected zeolites: Zeolite Socony Mobil 5 (ZSM-5); natural Jordanian zeolite (intermediate silica); MOR zeolites with a $\mathrm{SiO}_{2} / \mathrm{Al}_{2} \mathrm{O}_{3}$ of 18 (MOR18), 200 (MOR200), 240 (MOR240), and 400 (MOR400); modified MOR with an $\mathrm{SiO}_{2} / \mathrm{Al}_{2} \mathrm{O}_{3}$ 
ratio of 18 and 240 (TMOR18, TMOR240); magnetic nanoparticles-coated zeolite (MNCZ); zeolite Y; MOR; Slovak natural zeolites from Košice, Slovakia (Zeocem); and FAU-type zeolites (FAU-1, FAU-2). These zeolites were selected thanks to their proven effectiveness in removing antibiotics and non-steroidal drugs from aqueous solutions in studies published to date.

\subsection{Mesoporous Silica Materials (MCM-41 and SBA-15)}

The International Union of Pure and Applied Chemistry (IUPAC) classification defines mesoporous silica materials as porous materials with pores, fissures, cavities, or channels that are deeper than their width [100]. Their pore diameter is in the range of 2-50 nm. According to the IUPAC definition, porous materials also include zeolites, activated carbons, and silica gels. Mesoporous silica materials have gained great interest as they have very small pores that can allow the sorption of large molecules [101,102]. MCM-41 was the first mesoporous silica material to be reported and was described in the Journal of the American Chemical Society and Nature by scientists from the Mobil Research and Development Centre. In turn, in 1998, Zhao et al. synthesized a material that was first described as SBA-15 [103-105], which is considered to be the second most popular mesoporous silica material after MCM-41.

Mesoporous silica materials can be classified based on the conditions of synthesis$\mathrm{pH}$ (acidic (e.g., SBA-15) or slightly alkaline (e.g., MCM-41); type of surfactant used (ionic or nonionic), temperature, and amount of water in the synthesis system. The most popular mesoporous silica materials are MCM-41, MCM-48, MCM-50, SBA-15 and SBA16, KIT-1, FSM-16, and HMS [106,107]. This paper describes the properties of MCM-41 and SBA-15 in detail. These two materials were chosen taking into account their robust design as well as good stability and durability-the properties that make them attractive materials for use as adsorption platforms along mesochannels and allow good adsorptionadsorption interactions.

MCM-41 is a representative of the M41S family of compounds and has an orderly and periodically repeating structure. It is formed from quaternary ammonium salt surfactants. Hexadecyltrimethylammonium bromide (CTAB) is the surfactant most commonly used for synthesis and forms micelles with a positive surface charge. Tetraethoxysilane (TEOS) is usually used as a silica precursor [108]. MCM-41 possesses a hexagonal arrangement of cylindrical pores with a narrow diameter distribution and a large specific surface area. The pore diameter in the range of 1.5-10 nm makes MCM-41 a useful adsorbent for larger particles. Unlike the three-dimensional order found in classical crystals, MCM-41 is characterized by a two-dimensional order. Currently, MCM-41 is still one of the most frequently used types of mesoporous silica nanoparticles in adsorption, catalysis and controlled drug delivery, sensors, and electronics.

SBA-15 is obtained using amphiphilic triblock copolymers with different ratios of ethylene oxides (EOs) to propylene oxides (POs) of the poly EO (PEO)-poly PO (PPO)-PEO or PPO-PEO-PPO type. It is a silica-polymer phase with a hexagonal structure of p6mm symmetry [109]. The pore size of SBA-15 ranges from 5 to $30 \mathrm{~nm}$. The walls of SBA-15 are thicker than those of MCM-41 and range from 3 to $7 \mathrm{~nm}$. Both the pore size and wall thickness of silica can be controlled by appropriate temperature and aging time of the reaction solution $[109,110]$.

The application of mesoporous silica materials is constantly changing. Initially, they were used as molecular sieves with channels wider than zeolites. Their robust construction and long channels make them attractive adsorption materials that allow the diffusion of gases or liquids along the mesocanals and good adsorption-absorption interactions, as mentioned above. Today, mesoporous silica materials have many more potential applications compared with others. They are used to remove pharmaceuticals from water, which is confirmed by the results presented below. It is also possible to modify their properties through different processes (grafting and co-condensation) [111-113] or by cre- 
ating hybrid core/sheath structures, which allows new applications such as molecular printing $[114,115]$.

The widespread occurrence of pharmaceuticals in water indicates the inefficiency of conventional methods used for water and wastewater treatment. Therefore, there is a growing need to implement alternative technologies to optimize the absorption of pharmaceuticals. Among the different methods, adsorption is effective and does not produce unwanted by-products, thus it has been considered promising for removing pharmaceuticals from water and wastewater.

The costs of individual adsorbents depend on many factors (availability, processing requirements, recycling, and duration of use), which is hardly discussed in the literature. Sorbent costs differ based on country and location of use. Costs also vary depending on whether the sorbent is made from by-products of existing industries or is formed from chemically pure raw materials; for example, fly ash-based sorbents are typically produced at low cost. Thus, assessment of the cost of adsorbents is critical to selecting a suitable material for water treatment [116-118].

The adsorbent cost analysis should also take into account the factors that influence the determination of the cost of the adsorbent $[117,118]$, including treatment conditions, ease of adsorbate recovery, and reusability of the adsorbent. Pharmaceuticals present in wastewater reduce its mineralization by up to $20 \%$, which increases the cost of treatment [119]. This in turn has an impact on the use of adsorbents. Adsorption is more cost-effective than many other treatment methods [120], and the use of cheaper and sustainable adsorbents derived from waste products would further reduce the expenses.

It can be assumed that the cost of adsorption-based water treatment ranges from $\$ 10$ to $\$ 200$ per million liters, depending on the type and amount of adsorbent required [121]. On the other hand, the costs of electrodialysis, electrolysis, ion exchange, and reverse osmosis processes can be as high as $\$ 450$ per million liters [121]. Increased purification costs in advanced oxidation processes (AOPs) result from the use of chemicals [119] and energy consumption [122]. Adsorption is thus economically more viable. It also has additional advantages including high pharmaceutical removal rates $(>90 \%)$, low energy consumption, mild operating conditions, and no requirement for by-product addition to the system.

\section{Factors Affecting the Adsorption of NSAIDs and Antibiotics by Zeolites and Mesoporous Silica Materials}

\subsection{Characteristics of the Selected NSAIDs and Antibiotics}

Pharmacokinetic studies have shown that a significant proportion of the administered drugs is excreted in feces and urine [17,123], and thus occurs in domestic sewage. The discharge of expired medication into toilets is another source of wastewater contamination, which unfortunately is difficult to verify and estimate owing to a lack of reliable data. Wastewater discharges from drug production plants also contaminate water with pharmaceuticals [17]. After passing through wastewater treatment plants, pharmaceutical residues end up in surface waters, thereby contributing to the contamination of rivers and streams. The methods currently used for water and wastewater treatment ensure no or low-level purification of water from pharmaceutical residues and/or their metabolites, which results from the lack of appropriate standards and legal regulations forcing the use of appropriate sorption materials that will retain the specific pollutants. It is estimated that about three thousand different pharmaceutical substances are widely used, among which painkillers and antibiotics are the most common, followed by beta-blockers, antidepressants, and hormones [124]. The introduction of pharmaceuticals into the environment is determined by a number of integral factors influencing the pharmacological fate of the drug inside and outside the body. These factors include the degree of consumption of compounds, biotransformation processes, and the behavior of the drug or its metabolite during the wastewater treatment process [19].

NSAIDs are the most commonly used class of painkillers worldwide thanks to their availability over-the-counter (OTC) and frequent recommendations by doctors [125,126]. However, frequent use of NSAIDs has been reported to cause adverse drug reactions. 
These compounds act by blocking the activity of two isomeric forms of cyclooxygenase, namely COX-1 and COX-2. Cyclooxygenase is an enzyme that catalyzes the synthesis of prostaglandins, thromboxanes, and prostacyclins from arachidonic acid released from cell membrane phospholipids by phospholipases after cell stimulation $[48,127,128]$. The mechanism of action of NSAIDs was first elucidated by John Vane, who received a Nobel Prize for this research $[129,130]$.

Antibiotics, which are another group of pharmaceuticals commonly found in water and wastewater, are emerging pollutants. They are widely prescribed to treat various types of infections thanks to their bactericidal or bacteriostatic effect. Both NSAIDs and antibiotics are excreted from the human or animal body in an unchanged form, or as biologically active metabolites after biotransformation [131,132]. Therefore, it seems necessary to retain these types of pollutants in wastewater treatment systems, using appropriately developed and selectively functionalized sorption materials such as zeolites or mesoporous silica materials. The characteristics of the selected substances are summarized in Tables 3 and 4.

Table 3. Characteristics of the discussed NSAIDs.

\begin{tabular}{|c|c|c|c|c|}
\hline Common Name & Diclofenac & Ibuprofen & Ketoprofen & Naproxen \\
\hline CAS Number & $15307-86-5$ & $15687-27-1$ & $22071-15-4$ & $22204-53-1$ \\
\hline Molecular weight & 296.15 & 206.28 & 254.28 & 230.26 \\
\hline $\mathrm{pKa}^{\mathrm{a}}$ & 4.15 & 4.91 & 4.45 & 4.15 \\
\hline $\log$ Kow $^{a}$ & 4.51 & 3.97 & 3.12 & 3.18 \\
\hline $\mathrm{CEC}^{\mathrm{b}}\left(\mathrm{ng} \mathrm{L}^{-1}\right)$ & 4560 & 194,711 & 48,978 & 827,999 \\
\hline Classification group & acetic acid derivatives & $\begin{array}{l}\text { propionic acid } \\
\text { derivatives }\end{array}$ & $\begin{array}{l}\text { propionic acid } \\
\text { derivatives }\end{array}$ & $\begin{array}{l}\text { propionic acid } \\
\text { derivatives }\end{array}$ \\
\hline $\begin{array}{c}\text { Therapeutic } \\
\text { use/mechanism of action }\end{array}$ & $\begin{array}{c}\text { NSAID/ } \\
\text { non-selective } \\
\text { COX inhibitor }\end{array}$ & $\begin{array}{c}\text { NSAID/ } \\
\text { non-selective } \\
\text { COX inhibitor }\end{array}$ & $\begin{array}{c}\text { NSAID/ } \\
\text { non-selective } \\
\text { COX inhibitor }\end{array}$ & $\begin{array}{c}\text { NSAID/ } \\
\text { non-selective } \\
\text { COX inhibitor }\end{array}$ \\
\hline Half-lives, hours & 2 & $1.2-2$ & $1.1-4$ & $12-17$ \\
\hline Metabolite & $\begin{array}{c}\text { hydroxy metabolites, } \\
\text { glucuronic acid, sulfate, } \\
\text { and taurine }\end{array}$ & $\begin{array}{l}\text { hydroxylated and } \\
\text { carboxylated } \\
\text { derivatives }\end{array}$ & $\begin{array}{l}\text { glucuronide } \\
\text { metabolite }\end{array}$ & $\begin{array}{l}\text { desmethylnaproxen, } \\
\text { glucuronide metabolit }\end{array}$ \\
\hline References & [133] & {$[134,135]$} & [136] & {$[137,138]$} \\
\hline
\end{tabular}

Table 4. Characteristics of the discussed antibiotics.

\begin{tabular}{|c|c|c|c|c|}
\hline Common Name & Erythromycin & Sulphamethoxazole & Tetracycline & Trimethoprim \\
\hline CAS Number & $114-07-8$ & $723-46-6$ & $60-54-8$ & $738-70-5$ \\
\hline Molecular weight & 733.93 & 253.28 & 444.44 & 290.32 \\
\hline $\mathrm{pKa}^{\mathrm{a}}$ & 8.88 & $\begin{array}{l}1.6 \\
5.7\end{array}$ & 3.30 & 7.12 \\
\hline $\log$ Kow $^{a}$ & 3.06 & 0.89 & 1.37 & 0.91 \\
\hline $\mathrm{CEC}^{\mathrm{b}}\left(\mathrm{ng} \mathrm{L}^{-1}\right)$ & - & $9.8 \times 10^{7}$ & $6.7 \times 10^{7}$ & $3.3 \times 10^{6}$ \\
\hline Classification group & macrolide antibiotic & sulfonamides & tetracyclines & anisoles \\
\hline $\begin{array}{c}\text { Therapeutic } \\
\text { Use/mechanism of action }\end{array}$ & $\begin{array}{c}\text { Antibiotic/ } \\
\text { bacteriostatic }\end{array}$ & $\begin{array}{c}\text { Antibiotic/ } \\
\text { bacteriostatic }\end{array}$ & $\begin{array}{c}\text { Antibiotic/ } \\
\text { bacteriostatic }\end{array}$ & $\begin{array}{l}\text { Antibiotic/ } \\
\text { bactericidal }\end{array}$ \\
\hline Half-lives, hours & $2-3.5$ & 10 & $6-12$ & $8-10$ \\
\hline Metabolite & $\mathrm{N}$-desmethylerythromycin & $\begin{array}{l}\text { hydroxysulfamethoxazole, } \\
\text { acetylsulfamethoxazole } \\
\text { ulfamethoxazole } \\
\text { N4-hydroxylamine, } \\
\text { sulfamethoxazole } \\
\text { N-glucuronide }\end{array}$ & not metabolized & $\begin{array}{c}\text { demethylated } 3^{\prime} \text { - and } \\
4^{\prime} \text {-metabolite }\end{array}$ \\
\hline References & {$[139,140]$} & {$[141,142]$} & [143] & {$[142,144]$} \\
\hline
\end{tabular}

${ }^{a}$ Data were adopted from other sources $[145,146] ;{ }^{b}$ CEC values were adopted from [147]; ${ }^{a}$ pKa — dissociation constant, ${ }^{a}$ log Kow

—octanol-water partition coefficient, CEC—critical environmental concentration. 


\subsection{Methods of Extraction and Determination of NSAIDs and Antibiotics in the Aquatic Environment}

The presence of various pharmaceutical residues in very low concentrations in water and wastewater necessitates the development of sensitive methods for their determination. An extraction technique commonly used to isolate pharmaceuticals is solid-phase extraction (SPE), which enables to determine the concentration of the isolated compounds, especially those present in trace amounts such as NSAIDs and antibiotics. A wide variety of sorbents are used in the SPE process, thus choosing the appropriate filling can significantly influence the recovery of the drugs. A properly selected SPE cartridge allows optimizing the extraction conditions for many analyzed samples. Currently, the sorbents most often used to enrich environmental matrices, for drug analysis of residues, are silica-based or polymer sorbents. Liquid chromatography coupled with mass spectrometry is widely applied for separating pharmaceuticals. Table 5 summarizes the analytical methods used for water and wastewater samples for the determination of the analyzed compounds [148-156].

Table 5. Methods used for the extraction and determination of the analyzed compounds.

\begin{tabular}{|c|c|c|c|c|}
\hline Common Name & Extraction Technique/Sorbent & Determination Method & $\begin{array}{c}\text { Level } \\
\left(\mu \mathrm{g} \mathrm{L}^{-1}\right)\end{array}$ & Reference \\
\hline \multirow{5}{*}{ Diclofenac } & & & $2.0-6.30$ & \\
\hline & SPE/polymer & LC-MS/MS & $0.91-1.90$ & [148] \\
\hline & & & $0.18-2.60$ & \\
\hline & SPE/hydrophilic-lipophilic polymer & LC-MS & 0.116 & [149] \\
\hline & SPE/hydrophilic-lipophilic polymer & LC-MS & $0.113-4.882$ & [150] \\
\hline Ibuprofen & $\begin{array}{c}\text { SPE/ } \\
\text { hydrophilic-lipophilic polymer }\end{array}$ & LC-MS/MS & 27.30 & [151] \\
\hline Ketoprofen & $\begin{array}{c}\text { SPE/ } \\
\text { hydrophilic-lipophilic polymer }\end{array}$ & LC-MS & $0.031-3.511$ & [150] \\
\hline \multirow{2}{*}{ Naproxen } & $\begin{array}{c}\text { SPE/ } \\
\text { hydrophilic-lipophilic polymer }\end{array}$ & LC-MS & 22.50 & [149] \\
\hline & $\begin{array}{c}\text { SPE/ } \\
\text { hydrophilic-lipophilic polymer }\end{array}$ & LC-MS/MS & 19.90 & [151] \\
\hline \multirow{2}{*}{ Erythromycin } & $\begin{array}{c}\text { SPE/ } \\
\text { hydrophilic-lipophilic polymer }\end{array}$ & LC-MS & $0.509-0.149$ & [152] \\
\hline & $\begin{array}{c}\text { SPE/ } \\
\text { hydrophilic-lipophilic polymer }\end{array}$ & LC-MS/MS & 0.785 & [153] \\
\hline \multirow{3}{*}{ Sulphamethoxazole } & \multirow{3}{*}{$\begin{array}{c}\text { SPE/polymer } \\
\text { SPE/ } \\
\text { hPE/ } \\
\text { hydrophilic-lipophilic polymer } \\
\text { hydrophilic-lipophilic polymer }\end{array}$} & LC-MS & $0.376-0.572$ & [154] \\
\hline & & LC-MS & 2.060 & [149] \\
\hline & & LC-MS/MS & 0.024 & [153] \\
\hline Tetracycline & $\begin{array}{c}\text { SPE } \\
\text { /hydrophilic-lipophilic polymer }\end{array}$ & LC-MS & 146.0 & [155] \\
\hline \multirow{3}{*}{ Trimethoprim } & $\begin{array}{c}\text { SPE } \\
\text { /hydrophilic-lipophilic polymer }\end{array}$ & LC-MS/MS & 0.007 & [156] \\
\hline & $\begin{array}{l}\text { SPE/ } \\
\text { polymer }\end{array}$ & LC-MS & $0.27-0.94$ & [154] \\
\hline & $\begin{array}{c}\text { SPE } \\
\text { /hydrophilic-lipophilic polymer }\end{array}$ & LC-MS & 1.140 & [149] \\
\hline
\end{tabular}

Zeolites are increasingly tested in studies on pharmaceutical residues for determining the preconcentration of aqueous samples in the solid-phase dispersion extraction technique [153-156]. This technique is characterized by a short experiment time and low reagent consumption, and the use of zeolites as sorbents for pharmaceuticals allows high analyte recovery. 


\section{Potential Applications of Zeolites and Mesoporous Silica Materials in Water Treatment-Discussion}

4.1. Adsorption of Selected NSAIDs (Sodium Diclofenac, Ibuprofen, and Naproxen) and Selected Antibiotics (Erythromycin and Sulfamethoxazole) on Zeolites

The improvement of the sorption of diclofenac sodium was influenced by both the geometry of the pores and molecules of the hierarchical zeolite ZSM-5, as well as the interaction with active sites [157]. The BET surface areas of zeolite ZMS-5 and hierarchical zeolite ZMS-5 are shown in Figure 3. In turn, with the use of natural Jordanate zeolite (intermediate silica), it was observed that diclofenac sodium was sorbed best at $\mathrm{pH} 6$ (Figure 4, Table 6). This is because the diclofenac sodium cation can then penetrate the pores of the zeolite. Removal is very fast because, after $10 \mathrm{~min}$, the maximum removal percentage was achieved, similar to $\mathrm{MNCZ}$, in which increasing the contact time was found to have no significant effect on the adsorption of sodium diclofenac [158]. More efficient removal of diclofenac sodium was noted when its initial concentration was higher, because intense interactions occur between the natural zeolite and diclofenac sodium [159]. The use of MOR modified with $\mathrm{TiO}_{2}$, which has an $\mathrm{SiO}_{2} / \mathrm{Al}_{2} \mathrm{O}_{3}$ ratio of 18 and 240 (TMOR18 and TMOR240), made it possible to conclude that adsorption of sodium diclofenac is more effective on zeolites with a higher $\mathrm{SiO}_{2} / \mathrm{Al}_{2} \mathrm{O}_{3}$ ratio because of the fact that these zeolites are more hydrophobic [160] and have lower negative charges than those with a lower $\mathrm{SiO}_{2} / \mathrm{Al}_{2} \mathrm{O}_{3}$ ratio [161]. Data on the structural parameters of the starting materialsMOR zeolites with an $\mathrm{SiO}_{2} / \mathrm{Al}_{2} \mathrm{O}_{3}$ ratio of 18 and 240 (MOR18, MOR240), on which the modifications were made-are presented in Figure 3. On the other hand, sorption of diclofenac sodium on MNCZ confirmed the observations made by Al-rimawi et al. that the removal is more selective in solutions with an acidic $\mathrm{pH}$ [158] (Figure 4, Table 6).

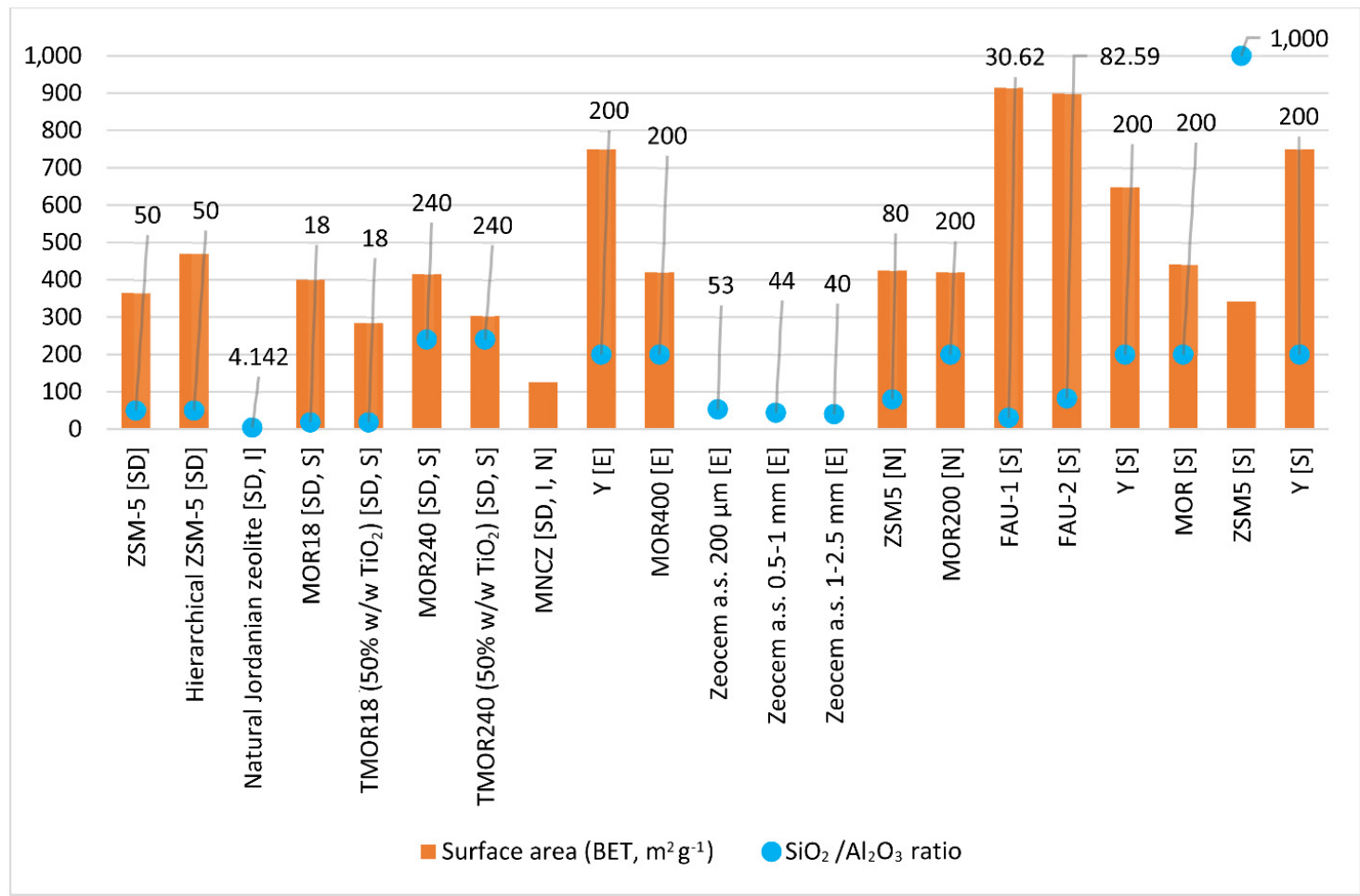

Figure 3. Structural properties of zeolites described in the literature for the removal of selected NSAIDs ([SD]—sodium diclofenac, $[\mathrm{I}]$ —ibuprofen, and [N]—naproxen) and selected antibiotics ([E]—erythromycin and [S]—sulfamethoxazole), ZSM-5 [SD], hierarchical ZSM-5 [SD]—[157]; natural Jordanian zeolite [SD, I]—[159] MOR18 [SD, S], TMOR18 (50\% (w/w) $\left.\mathrm{TiO}_{2}\right)$ [SD, S], MOR240 [SD, S], TMOR240 (50\% $\left.(w / w) \mathrm{TiO}_{2}\right)$ [SD, S]-[162]; MNCZ [SD, I, N]-[163]; Y [E], MOR400 [E]-[98]; Zeocem a.s. $200 \mu \mathrm{m}$ [E], Zeocem a.s. 0.5-1 $\mathrm{mm}$ [E], Zeocem a.s. 1-2.5 mm [E]-[164]; ZSM-5 [N], MOR200 [N]-[99]; FAU-1 [S], FAU-2 [S]-[62]; Y [S], MOR [S], ZSM-5 [S]—[165]; Y [S]—[166]. 


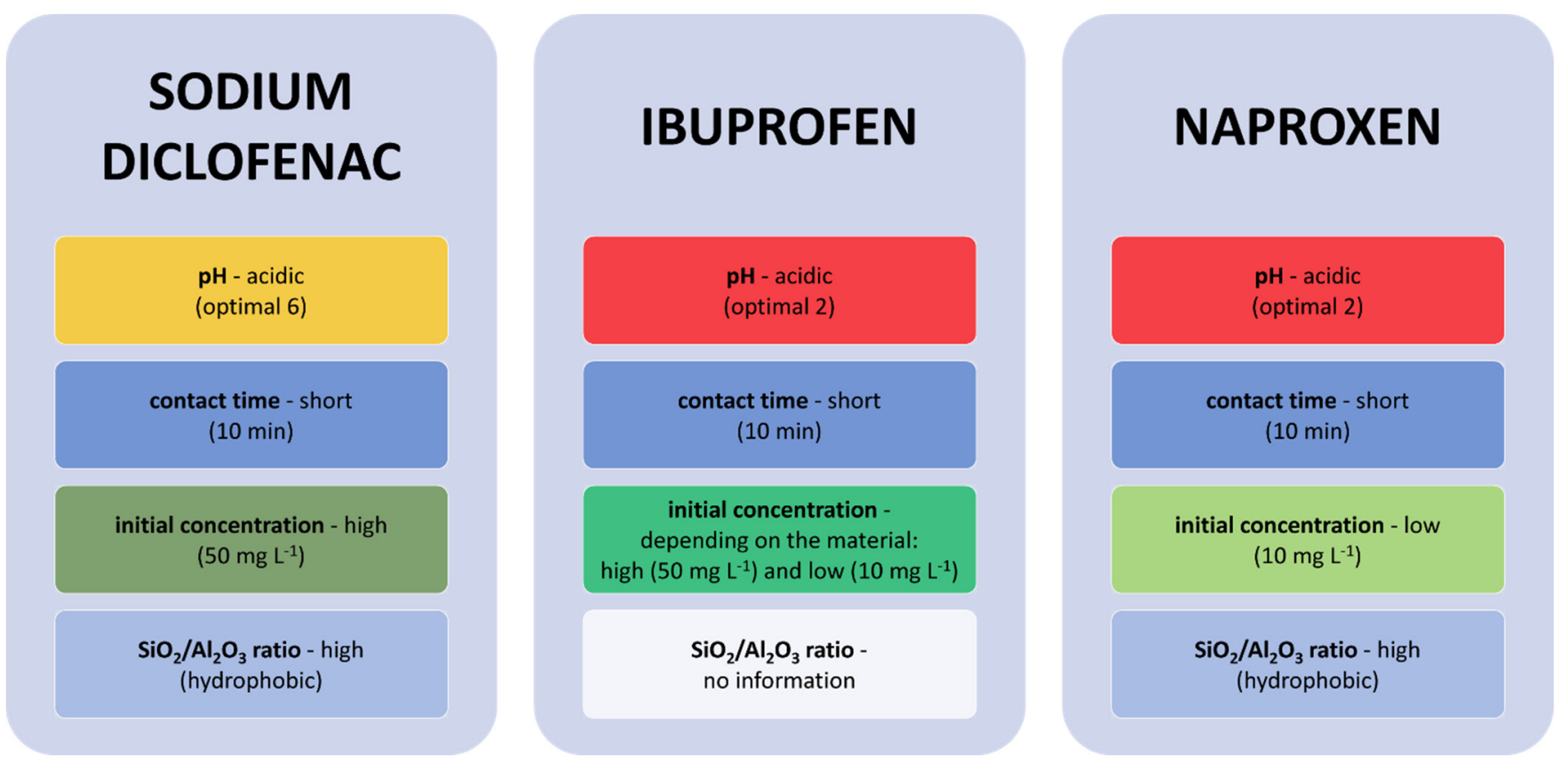

Figure 4. Factors influencing the removal efficiency of selected zeolites: sodium diclofenac-ZSM-5, hierarchical ZSM5, natural Jordanian zeolite (intermediate silica), TMOR18, TMOR240, MNCZ; ibuprofen—natural Jordanian zeolite (intermediate silica), MNCZ; naproxen-MNCZ, ZSM-5, MOR200.

Table 6. Parameters of zeolites for the removal of selected NSAIDs (diclofenac, ibuprofen, and naproxen) and selected antibiotics (erythromycin, sulfamethoxazole, tetracycline, and trimethoprim).

\begin{tabular}{|c|c|c|c|c|c|c|c|}
\hline Adsorbate & $\begin{array}{c}\text { Framework Type of Zeolite } \\
\text { (Si/Al Ratio) }\end{array}$ & $\begin{array}{c}\text { Dose } \\
\left(\mathrm{g} \mathrm{L}^{-1}\right)\end{array}$ & $\begin{array}{l}\text { Contact } \\
\text { Time (h) }\end{array}$ & $\begin{array}{c}\mathrm{T} \\
\left({ }^{\circ} \mathrm{C}\right) \\
\end{array}$ & Concentrations & $\mathrm{pH}$ & Reference \\
\hline $\begin{array}{l}\text { Sodium } \\
\text { diclofenac }\end{array}$ & $\begin{array}{c}\text { zeolite ZSM-5 } \\
\text { hierarchical ZSM-5 }\end{array}$ & 0.05 & 1.0 & 29.85 & $10-1000 \mu \mathrm{M}$ & - & [157] \\
\hline $\begin{array}{l}\text { Sodium } \\
\text { diclofenac }\end{array}$ & $\begin{array}{l}\text { natural Jordanian zeolite } \\
\text { (intermediate silica) }\end{array}$ & 2.0 & 1.2 & - & $\begin{array}{c}10.0 ; 20.0 \\
40.0 \\
50.0 \times 10^{4} \mu \mathrm{g} \mathrm{L}^{-1} \\
\end{array}$ & 6.0 & [159] \\
\hline $\begin{array}{l}\text { Sodium } \\
\text { diclofenac }\end{array}$ & $\begin{array}{c}\text { TMOR18 }\left(50 \% w / w \mathrm{TiO}_{2}\right) \\
\text { TMOR240 }\left(50 \% w / w \mathrm{TiO}_{2}\right)\end{array}$ & 0.7 & - & - & $100 \mu \mathrm{g} \mathrm{L}^{-1}$ & - & [162] \\
\hline $\begin{array}{l}\text { Sodium } \\
\text { diclofenac }\end{array}$ & MNCZ & 0.05 & - & $30 \pm 1$ & $100 \mu \mathrm{g} \mathrm{L}^{-1}$ & $2.0-9.0$ & [158] \\
\hline Erythromycin & zeolite $\mathrm{Y}$ & - & - & - & $0-5 \times 10^{3} \mu \mathrm{g} \mathrm{L}^{-1}$ & - & [98] \\
\hline Erythromycin & $\begin{array}{c}\text { Zeocem a.s. } 200 \mu \mathrm{m} \\
\text { Zeocem a.s. } 0.5-1 \mathrm{~mm} \\
\text { Zeocem a.s. } 1-2.5 \mathrm{~mm}\end{array}$ & 0.05 & 0.5 & - & $\begin{array}{l}0.016 \mu \mathrm{g} \mathrm{L}^{-1} \\
0.037 \mu \mathrm{g} \mathrm{L}^{-1}\end{array}$ & $\begin{array}{l}\mathrm{pH}=6.85 \\
\mathrm{pH}=7.01\end{array}$ & [164] \\
\hline Ibuprofen & $\begin{array}{l}\text { natural Jordanian zeolite } \\
\text { (Intermediate silica) }\end{array}$ & 1.0 & 1.2 & - & $\begin{array}{c}10.0 ; 20.0 ; 40.0 ; \\
50.0 \times 10^{4} \mu \mathrm{g} \mathrm{L}^{-1}\end{array}$ & 2.0 & [159] \\
\hline $\begin{array}{l}\text { Ibuprofen } \\
\text { Naproxen }\end{array}$ & MNCZ & 0.05 & - & $30 \pm 1$ & $100 \mu \mathrm{g} \mathrm{L}^{-1}$ & $2.0-9.0$ & [158] \\
\hline Naproxen & $\begin{array}{c}\text { ZSM5 } \\
\text { MOR200 }\end{array}$ & 0.05 & - & - & $2 \mu \mathrm{g} \mathrm{L} \mathrm{L}^{-1}$ & 6.0 & [99] \\
\hline Sulfametoksazole & $\begin{array}{l}\text { FAU-1 } \\
\text { FAU-2 }\end{array}$ & 0.50 & 2.0 & - & $1.0 \times 10^{5} \mu \mathrm{g} \mathrm{L}^{-1}$ & 6.5 & [62] \\
\hline Sulfamethoxazole & $\begin{array}{c}\text { zeolite Y } \\
\text { MOR } \\
\text { ZSM5 }\end{array}$ & 0.50 & 24.0 & $\begin{array}{l}21 \\
21 \\
65\end{array}$ & $30 \mu \mathrm{M}$ & - & [165] \\
\hline Sulphamethoxazole & $\begin{array}{c}\text { TMOR18 }\left(50 \% w / w \mathrm{TiO}_{2}\right) \\
\text { TMOR240 }\left(50 \% w / w \mathrm{TiO}_{2}\right)\end{array}$ & 0.70 & - & - & $100 \mu g \mathrm{~L}^{-1}$ & - & [162] \\
\hline Sulphamethoxazole & zeolite $\mathrm{Y}$ & 0.50 & 1.0 & - & $50 \mu \mathrm{M}$ & $5-8$ & {$[166]$} \\
\hline
\end{tabular}


Studies on Jordanate natural zeolite showed that ibuprofen is removed effectively when the $\mathrm{pH}$ is acidic and the optimal $\mathrm{pH}$ is 2 [159]. This result was also confirmed when MNCZ was used as an adsorbent [158]. The contact time may be short, and $10 \mathrm{~min}$ is sufficient for effective removal (Figure 4, Table 6). If the initial concentration is high, resistance to mass transfer of pharmaceutical molecules between the aqueous and solid phases of Jordanate natural zeolite is quickly overcome [159]. On the other hand, for MNCZ, the efficiency of ibuprofen removal decreases at higher concentrations and improves at lower concentrations [158].

ZSM-5 and MOR zeolites having an $\mathrm{SiO}_{2} / \mathrm{Al}_{2} \mathrm{O}_{3}$ ratio of 200 (MOR200), which were used to remove naproxen, were in a powdered form. Data on the $\mathrm{SiO}_{2} / \mathrm{Al}_{2} \mathrm{O}_{3}$ ratios presented in Figure 3 show that MOR200 zeolite is more hydrophobic compared with ZSM-5 zeolite. It was confirmed that lower sorption of naproxen occurs at alkaline $\mathrm{pH}$, which may be caused by the increase in the amount of hydroxyl ions and formation of water complexes delaying sorption (Figure 4, Table 6). Naproxen sorption occurs quickly, and the contact time required for removal is only $10 \mathrm{~min}$ [158]. Removal occurs better with zeolites having a higher $\mathrm{SiO}_{2} / \mathrm{Al}_{2} \mathrm{O}_{3}$ ratio [99] and a low initial concentration [158].

Three zeolites were used to remove erythromycin, including two synthetic ones (MOR zeolites with an $\mathrm{SiO}_{2} / \mathrm{Al}_{2} \mathrm{O}_{3}$ ratio of $400-\mathrm{MOR} 400$ and $\mathrm{Y}$ zeolite) and natural Slovak zeolite from Zeocem a.s. with different fractions $(200 \mu \mathrm{m}, 0.5-1 \mathrm{~mm}$, and 1-2.5 mm). The characteristics of MOR400 and zeolite $\mathrm{Y}$ are presented in Figure 3. Zeolite turned out to be a better synthetic sorbent, which was proved by TG curve and XRD analyses. The analyses showed that adsorption of erythromycin occurred in the entire zeolite structure, as well as in micropores [98]. Erythromycin removal from wastewater (concentrations: $16.0 \mathrm{ng} \mathrm{L}^{-1}$ —Stupava treatment plant; $37.0 \mathrm{ng} \mathrm{L}^{-1}$ —Devínska Nová Ves treatment plant) was tested using natural zeolite Zeocem a.s. with three fractions. A 30 min contact time resulted in over $90 \%$ removal at both concentrations for the finer fraction. Such high efficiency was achieved because the $\mathrm{pH}$ condition was optimal (the $\mathrm{pH}$ of the wastewater must be lower than the pKa of erythromycin, i.e., 8.88) [164] (Table 6). Studies investigating the adsorption efficiency of zeolite $Y$ were carried out using water collected at the outlet of a wastewater treatment plant in Ferrara (northern Italy), where the actual concentration of erythromycin was $1.10 \mathrm{\mu g} \mathrm{g}^{-1}$, and the results confirmed that $100 \%$ removal was achieved with this zeolite [98].

The contact time needed to remove sulfamethoxazole is $15-30 \mathrm{~min}$, and the optimal $\mathrm{pH}$ is 2 (Table 6). For the $\mathrm{pH}$ found in the wastewater (i.e., 7.25), an elimination efficiency of $43 \%$ was achieved [62]. The removal of sulfamethoxazoles is effective on high-silicon zeolites [166]. The characteristics of zeolites are presented in Figure 3. Studies carried out using MOR and ZSM-5 zeolites proved that temperature influences the effectiveness of sorption. Sorption with MOR was more effective at RT, while better results for ZSM- 5 were achieved at the temperature of $65^{\circ} \mathrm{C}$. Research also showed that the efficiency of sorption on individual zeolites is influenced by the initial concentration; for low concentrations $(20 \mu \mathrm{M})$ of contaminants, it is best to use zeolite $\mathrm{Y}$, while for high concentrations $(180 \mu \mathrm{M})$, ZSM-5 can work better. A positive aspect of using zeolite Y, MOR, and ZSM-5 is the fact that sorption is irreversible [165]. Of these sorbents, zeolite $Y$ turned out to be the best. Modification of MOR18 zeolite with $\mathrm{TiO}_{2}$ significantly increased the adsorption of sulfamethoxazole [162] (Figure 5).

Al-Rimawi and colleagues (2019) studied the removal of sodium diclofenac and ibuprofen using natural zeolite Jordanate (intermediate silica). They determined that the optimum $\mathrm{pH}$ for ibuprofen is 2 and for sodium diclofenac is 6 . Their study showed that, based on the chemical structure of zeolites, at a low ibuprofen concentration, the drug will interact with zeolite through a relatively strong interaction of the carboxylic group and oxygen atoms combined with silicon and aluminium elements. At $\mathrm{pH} 6$, sodium diclofenac may participate in strong interactions with zeolite molecules through the following mechanism: sodium cation may penetrate the pores of the zeolite and participate in electrostatic interactions between the cation and amine group of diclofenac. 
Removal of sodium diclofenac on the zeolite may be related to the fact that, at higher values, the proton concentration $\left(\mathrm{H}^{+}\right)$is reduced, and thus its competition with sodium cations for binding to diclofenac is minimal, which results in stronger interactions between the drug and the zeolite (drug amine and sodium cation are in the zeolite pores).

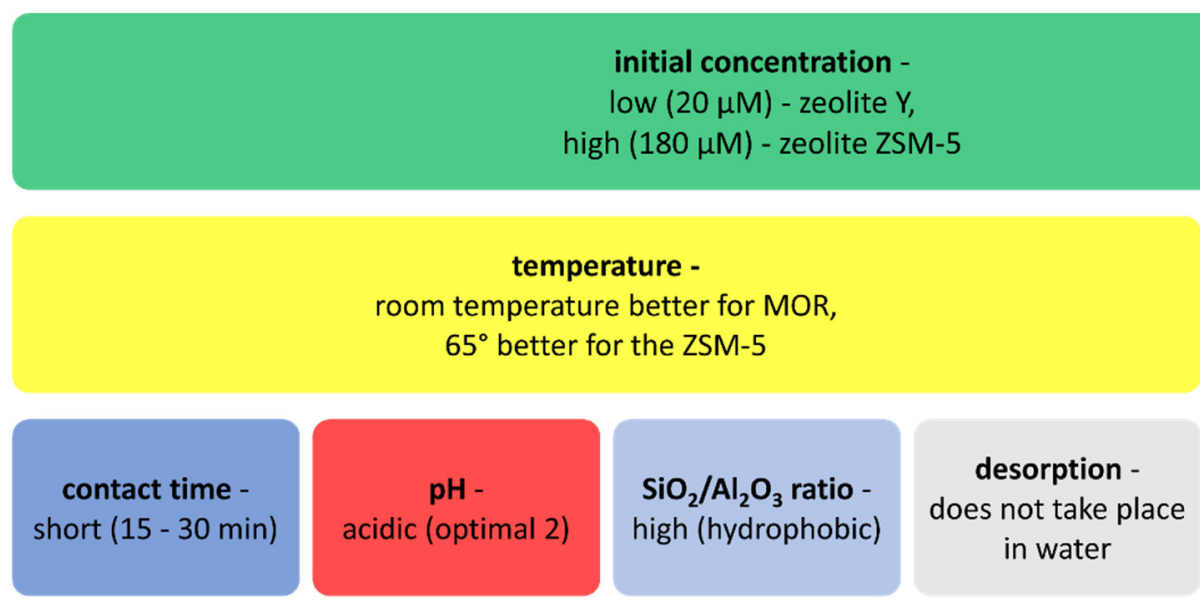

Figure 5. Factors influencing the sorption of sulfamethoxazole on zeolites: FAU-1, FAU-2, zeolite Y, MOR, ZSM-5, TMOR18, and TMOR240.

It was observed that, in the case of both diclofenac and ibuprofen, the maximum removal percentage was reached after $10 \mathrm{~min}$, but the optimum contact time was taken as $80 \mathrm{~min}$ to ensure appropriate contact. The maximum removal of sodium diclofenac was estimated at $2.0 \mathrm{~g} \mathrm{~L}^{-1}$ and of ibuprofen at $1.0 \mathrm{~g} \mathrm{~L}^{-1}$. The concentrations of both pharmaceuticals were tested in the range of $10-50 \mathrm{mg} \mathrm{L}^{-1}$. The ability to remove both medicines increased with the increasing concentration. This effect can be explained as follows: a higher initial concentration increases the driving force, which allows overcoming the resistance to mass transfer of pharmaceutical molecules between the aqueous and solid phases. Moreover, the increase in absorption capacity with increasing starting concentration may also result from a more intense interaction between the natural zeolite and medicines. The authors determined the adsorption capacity of the tested zeolite for sodium diclofenac at $4.8 \mathrm{mg} \mathrm{g}^{-1}$ according to the Langmuir isotherm and for ibuprofen at $1.23 \mathrm{mg} \mathrm{g}^{-1}$ according to the Freundlich isotherm [159].

Modifications of MOR with an $\mathrm{SiO}_{2} / \mathrm{Al}_{2} \mathrm{O}_{3}$ ratio of 18 and 240 (coated with "Kronoclean 7000" (Kronos, Germany) and $\mathrm{TiO}_{2}$ powder, designated as modified MOR, with an $\mathrm{SiO}_{2} / \mathrm{Al}_{2} \mathrm{O}_{3}$ ratio of 18 and 240 (TMOR18 and TMOR240), were carried out to remove pharmaceuticals such as diclofenac and sulfamethoxazole. Modification with $\mathrm{TiO}_{2}$ powder caused the specific surface area (BET) to decrease, but allowed the formation of new mesopores and macropores. The effects of surface reduction and micropore formation of TMOR18 and TMOR240 zeolites did not have a significant impact on the adsorption of medicines. However, the $\mathrm{SiO}_{2} / \mathrm{Al}_{2} \mathrm{O}_{3}$ ratio in the structure of zeolites influenced the adsorption of pharmaceuticals because zeolites with a higher $\mathrm{SiO}_{2} / \mathrm{Al}_{2} \mathrm{O}_{3}$ ratio are more hydrophobic and have lower negative charges compared with those with lower $\mathrm{SiO}_{2} / \mathrm{Al}_{2} \mathrm{O}_{3}$ ratios. On TMOR240, diclofenac was removed only by $20-30 \%$. Diclofenac has a negative charge, which can cause electrostatic repulsion between MOR240 and the drug. However, the negative surface charge of TMOR240 was assumed to be quite low. Modification with $\mathrm{TiO}_{2}$ zeolite MOR240 and MOR18 showed almost an insignificant influence on the adsorption of the tested medicines, except for the adsorption of sulfamethoxazole on TMOR18. On the other hand, modification of MOR18 zeolite with $\mathrm{TiO}_{2}$ significantly increased the adsorption of sulfamethoxazole because the surface was negatively charged [162].

Various sorption parameters, such as contact time, solution $\mathrm{pH}$, and initial concentration (diclofenac sodium, ibuprofen, and naproxen), were investigated to optimize the reaction conditions for magnetic nanoparticles coated zeolite (MNCZ). The $\mathrm{pH}$ of the 
solution affects the removal efficiency of the tested pharmaceuticals. However, it has been proved that, as the $\mathrm{pH}$ changes from acidic to alkaline conditions, the tested compounds are less efficiently removed on MNCZ. Lower sorption efficiency was observed at an alkaline $\mathrm{pH}$, which may be due to an increase in the amount of hydroxyl ions and the formation of aqueous complexes, delaying sorption. Consequently, the values of adsorption observed for a solution with a $\mathrm{pH}$ of 2.0 were $99.58 \%$ for diclofenac sodium, $98.75 \%$ for ibuprofen, and $99.79 \%$ for naproxen, while the values determined for a solution with $\mathrm{pH} 11.0$ were $93.99 \%, 90.79 \%$, and $90.69 \%$, respectively. Although pH was an important factor influencing sorption on $\mathrm{MNCZ}$, it was proved that this material had a high ability to remove tested medicines over a wide $\mathrm{pH}$ range (2-9). This information is very important for the future use of MNCZ for drinking water and/or wastewater treatment. The time of contact with MNCZ had no significant effect on the adsorption of diclofenac sodium, and MNCZ showed a high potential to adsorb ibuprofen and naproxen. The removal efficiency was over $95 \%$ after just $10 \mathrm{~min}$. The starting concentration had no significant effect on the removal efficiency of the tested pharmaceutical at low concentrations. Nevertheless, a significant reduction in the removal efficiency of the tested compounds, especially ibuprofen, was observed with an increase in its concentration [158].

4.2. Adsorption of Selected NSAIDs (Diclofenac, Ibuprofen, and Ketoprofen) and Selected Antibiotics (Sulfamethoxazole, Tetracycline, and Trimethoprim) on MCM-41 and SBA-15

Inorganic mesoporous silica materials such as SBA-15 and MCM-41 are alternative adsorbents used for water treatment [55]. They are characterized by high porosity, uniform and narrow pore sizes, ordered arrangement of pore structures, large pore volume, and large surface area, which increases their adsorption capacity. Langmuir and Freundlich isothermal parameters that determine the adsorption of pharmaceuticals from aqueous solutions are listed in Table 7 for selected MCM-41 and SBA-15 adsorbents and selected NSAIDs and antibiotics. These silica-based porous materials have already been used to remove pharmaceutical residues by other researchers [167].

SBA-15 material was used in two independent studies for the removal of diclofenac, ibuprofen, and ketoprofen (Figure 6). The contact time needed to remove these three NSAIDs was $<15 \mathrm{~min}$ [168], while two other studies showed that the required contact time was $30 \mathrm{~min}[55,169]$. This can be because of the ordered mesoporous structure of the materials used in the research. SBA-15 showed better adsorption efficiency compared with MCM-41. The adsorption process was more effective at low $\mathrm{pH}$, which proves that the interaction occurring between drugs and the surface of mesoporous silica is hydrophilic [55,169]. Desorption of these pharmaceuticals in an alkaline environment was low, which indicates that they were strongly adsorbed to SBA-15, MCM-41, and TMS-SBA15 , whereas, with the use of ethanol, the desorption was found to be high $[55,168,169]$.

initial concentration - low and high (0.01-0.3 $\left.\mathrm{mg} \mathrm{L}^{-1}\right)$

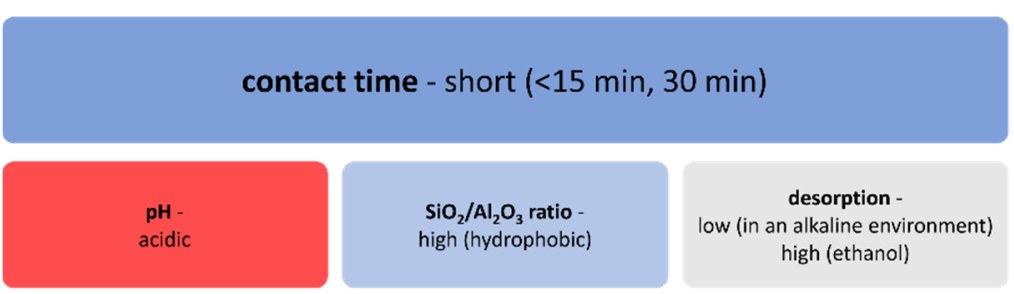

Figure 6. Factors influencing the sorption of diclofenac, ibuprofen, and ketoprofen on mesoporous materials: SBA-15, MCM-41, and TMS-SBA-15. 
Table 7. Comparative evaluation of adsorbent capacities for the removal of selected pharmaceuticals from aqueous solutions.

\begin{tabular}{|c|c|c|c|c|c|c|c|c|}
\hline Adsorbent & Adsorbate & $\mathrm{pH}$ & $\begin{array}{l}\text { Temp } \\
\left({ }^{\circ} \mathrm{C}\right)\end{array}$ & $\begin{array}{c}\text { Conc. } \\
\text { Range } \\
\left(\mathrm{mg} \mathrm{L}^{-1}\right)\end{array}$ & $\begin{array}{c}\text { Surface } \\
\text { Area } \\
\left(\mathrm{m}^{2} \mathrm{~g}^{-1}\right)\end{array}$ & $\begin{array}{c}\text { Freundlich } \\
\text { Sorption Capacity } \\
\text { (KF) }\end{array}$ & $\begin{array}{c}\text { Langmuir Sorption } \\
\begin{array}{c}\text { Capacity } \\
\left(\mathrm{mg} \mathrm{g}^{-1}\right)\end{array} \\
\end{array}$ & Reference \\
\hline MCM-41 & Diclofenac & 7.0 & 25 & $0.04-0.3$ & 755 & 0.05 & 0.11 & [168] \\
\hline SBA-15 & Diclofenac & 7.0 & 25 & $0.04-0.3$ & 890 & 0.11 & 0.13 & [168] \\
\hline SBA-15 & Diclofenac & 5.0 & 25 & $0.01-0.3$ & 737 & 0.72 & 0.34 & [55] \\
\hline SBA-15 & Ibuprofen & 5.0 & 25 & $0.01-0.3$ & 737 & 1.50 & 0.41 & [55] \\
\hline SBA-15 & Ketoprofen & 5.0 & 25 & $0.01-0.3$ & 737 & 1.09 & 0.28 & [55] \\
\hline AMCM-41 & Tetracycline & 7.0 & 30 & 300 & 485 & 368.58 & 415.10 & [170] \\
\hline AMCM-41 & Tetracycline & 7.0 & 40 & 300 & 485 & 364.21 & 417.50 & [170] \\
\hline AMCM-41 & Tetracycline & 7.0 & 50 & 300 & 485 & 362.15 & 419.30 & [170] \\
\hline
\end{tabular}

Sulfamethoxazole and trimethoprim were removed on TMS-SBA-15 material (Figure 7). The initial concentration of both of these antibiotics was high, yet adsorption occurred after a short contact time of $30 \mathrm{~min}$. Complete desorption of these antibiotics was achieved with the use of ethanol. One difference was noted in the effect of $\mathrm{pH}$ on the adsorption of these compounds. Sulfamethoxazole is an anionic compound; therefore, it was removed efficiently in low-pH solutions. On the other hand, trimethoprim is a cationic compound, and an increase in the $\mathrm{pH}$ of the solution made its sorption more effective [169]. A-MCM41-mesoporous material MCM-41 impregnated with zeolite A-was used to remove tetracycline in a study. Three high concentrations of the antibiotic were tested, and the results proved that tetracycline adsorption was most effective at the highest concentration. The removal process took $100 \mathrm{~min}$ (Figure 7) and, after this time, tetracycline adsorption was very slow, as most of the reactive sites were occupied [170].
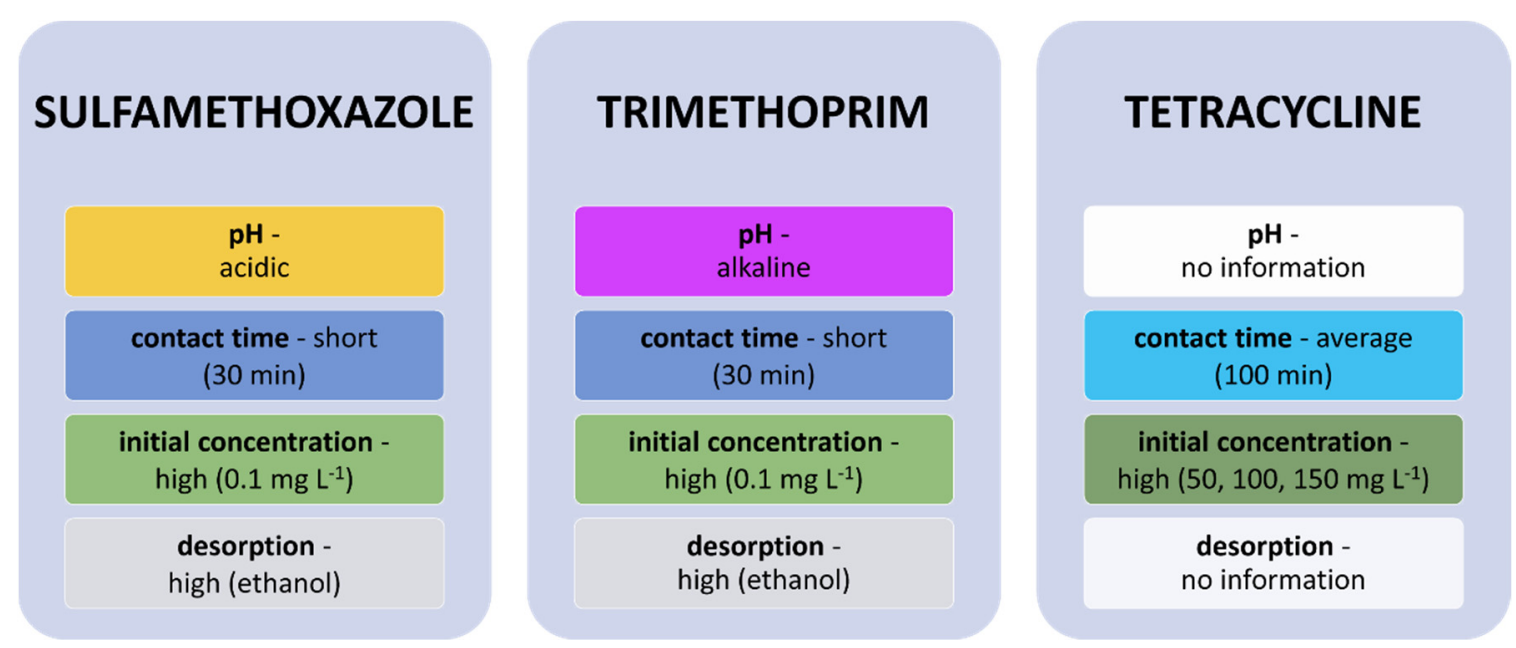

Figure 7. Factors influencing the sorption of sulfamethoxazole and trimethoprim on TMS-SBA-15 and tetracycline on A-MCM-41.

SBA-15 is a promising adsorbent for the removal of diclofenac, ibuprofen, and ketoprofen not only from surface water, but also from wastewater from the pharmaceutical industry, which have high concentrations of these pharmaceuticals. For SBA-15 $\left(2.0 \mathrm{~g} \mathrm{~L}^{-1}\right)$, the removal efficiency of diclofenac, ibuprofen, and ketoprofen was determined to be $66.7 \%$, $95.1 \%$, and $91.2 \%$, respectively. In the dose range of $0.1-1.0 \mathrm{~g} \mathrm{~L}^{-1}$ (SBA-15), the adsorption of diclofenac, ibuprofen, and ketoprofen increased almost linearly with an increase in the concentration of the adsorbent, but the increase in the adsorbent dose from 1.0 to $2.0 \mathrm{~g} \mathrm{~L}^{-1}$ did not have a significant effect. Adsorption of all medicines (diclofenac, ibuprofen, and ketoprofen) reached equilibrium in a very short time ( $<15 \mathrm{~min})$. This may be owing to the ordered mesoporous structure of SBA-15. The strongly pH-dependent adsorption of 
drugs suggests that the interaction between the drugs and the mesoporous silica surface is hydrophilic. Moreover, the low percentage of desorption of pharmaceuticals from the silica surface in alkaline media suggests that they are strongly adsorbed to SBA-15. After sorption, SBA-15 can be regenerated by combustion without any material losses, owing to the stability of the mesoporous silica structure at temperatures up to $850{ }^{\circ} \mathrm{C}$ [55].

\section{Summary and Perspectives}

Pharmaceuticals, which have long been present in the environment for 2-3 decades, are an environmental concern. They have been detected by various studies, and their dangerous effects on flora, fauna, and humans have been noticed [41,44,171-173]. Pharmacological contaminants are not completely removed in sewage treatment plants, which causes their migration to surface waters. For this reason, there is a constant search for advanced and effective processes for removing these pollutants. Adsorption and AOPs are processes that can be used to effectively remove medicines from water and wastewater. However, a disadvantage of AOPs is that they generate many oxidation and transformation by-products, some of which are toxic. Adsorption is advantageous over AOP, as it does not result in the formation of new products. However, it requires a large amount of adsorbent, which has consequences related to the sorbent itself, such as the need for regeneration or disposal after use, as well as consequences related to the adsorbed pharmaceuticals and their derivatives, which must be eliminated. Zeolites and mesoporous silica materials can be cheap adsorbents because they are both produced from fly ashes that are considered waste. The removal of NSAIDs and antibiotics using adsorption is currently applied on a laboratory scale or in small-scale implementation studies. After sorption, materials can often be used to improve soil properties or can be regenerated by burning without damaging their structure while destroying the adsorbed medicines. Tables 5 and 6 present the examples of zeolites and mesoporous silica materials used to remove selected NSAIDs (diclofenac, ibuprofen, ketoprofen, and naproxen) and selected antibiotics (erythromycin, sulfamethoxazole, tetracycline, and trimethoprim) from aqueous solutions. They also provide information on adsorption kinetics and the applied test conditions. Finally, this review is complemented by a commentary covering research on drugs in the environment. Pharmaceutical disposal is currently a growing and active area of research as new medicines are launched every year and their environmental impact is significant. The following points should thus be noted:

Wastewater treatment plants must adopt new technologies for the effective removal of pharmaceuticals.

The removal technologies should be affordable and easy to apply rapidly on a large scale at a low cost.

Standards defining the maximum allowable concentration should be implemented to reduce the amount of pharmaceuticals entering the environment (aquatic ecosystems) from wastewater treatment plants.

Advanced methods for accurate and continuous detection of drugs should be developed and applied, especially in rapidly developing industrial countries such as India and China.

Continuous research should be conducted on environmental systems to determine how pharmaceuticals affect flora, fauna, and microorganisms.

NSAIDs and antibiotics are two of the most frequently recommended pharmaceuticals and are essential in many cases for pain relief or to treat bacterial infections. These compounds are excreted from the human body either in an unchanged form or as metabolites after biotransformation, which unfortunately leads to their persistence in the environment and poses potential risks to the ecosystem. Therefore, it is necessary to investigate their sorption and disposal at the stage of wastewater treatment. It is also extremely important to develop an efficient and inexpensive technology for retaining these compounds on appropriate sorption beds as well as to legally regulate the need to introduce a stage for their retention in the wastewater treatment process. The development and implementation 
of a sorption procedure, based on zeolites or mesoporus materials, for modern NSAIDs and antibiotics may give rise to a wastewater treatment system that can also be used for other frequently used drugs such as hormones, antidepressants, anticancer substances, or beta-blockers.

Thus, this paper provides a thorough literature review on zeolites and mesoporous silica materials used to retain selected medicines. This review may be helpful to carry out further experimental studies aimed at creating an appropriate sorption bed for effectively retaining drugs. The review focused mainly on pharmaceuticals that are commonly used, but are chemically different in terms of structure and particle size. The sorption bed prepared using this approach will be universal and will enable retaining a wide range of undesirable chemical compounds in wastewater.

On the basis of the conducted analysis, future research should be carried out in terms of the use of the described materials as sorbents for pharmaceuticals from wastewater (and not only from solutions prepared in the laboratory). The materials used in the described research had a dusty form, which makes it difficult to use them in column flow experiments. For this reason, their granulation should be included in further considerations. The granulation process opens up many research opportunities related to, for example, the selection of appropriate consolidation processes. Subsequently, it is possible to study the effect of effective modification of the sorbent surface in order to increase the simultaneous co-sorption of cationic and anionic chemical compounds. It is also worth considering the methods of regeneration after sorption and re-use of materials in the same sorption process without losing sorption capacity, efficiency, and selectivity. Another issue that may be addressed in the future is the profitability of using modified sorbents or sorbents after regeneration. The cost of obtaining sorbents should be estimated and compared with materials generally available on the market.

Author Contributions: Conceptualization: A.G., T.B. and J.K. Visualization: A.G., T.B. and J.K. Writing-original draft: A.G. and J.K.; review and editing: T.B. All authors have read and agreed to the published version of the manuscript.

Funding: This research was funded by the Foundation for Polish Science POIR.04.04.00-00-14E6/18-00 under the project "Fly ashes as the precursors of functionalized materials for applications in environmental engineering, civil engineering, and agriculture" carried out within the TEAM-NET program.

Acknowledgments: This work was conducted under the project "Fly ashes as the precursors of functionalized materials for applications in environmental engineering, civil engineering, and agriculture" carried out within the TEAM-NET program of the Foundation for Polish Science POIR.04.04.00-0014E6/18-00.

Conflicts of Interest: The authors declare no conflict of interest.

\section{References}

1. Kümmerer, K. The presence of pharmaceuticals in the environment due to human use-Present knowledge and future challenges. J. Environ. Manag. 2009, 90, 2354-2366. [CrossRef]

2. Rivera-Utrilla, J.; Sanchez-Polo, M.; García Maria Ángeles, F.; Prados-Joya, G.; Perez, R.O. Pharmaceuticals as emerging contaminants and their removal from water. A review. Chemosphere 2013, 93, 1268-1287. [CrossRef] [PubMed]

3. Rivera-Utrilla, J.; Gómez-Pacheco, C.V.; Sanchez-Polo, M.; Peñalver, J.J.L.; Perez, R.O. Tetracycline removal from water by adsorption/bioadsorption on activated carbons and sludge-derived adsorbents. J. Environ. Manag. 2013, 131, 16-24. [CrossRef] [PubMed]

4. Bush, K. Antimicrobial agents. Curr. Opin. Chem. Biol. 1997, 1, 169-175. [CrossRef]

5. Halling-Sørensen, B.; Nielsen, S.N.; Lanzky, P.; Ingerslev, F.; Lützhøft, H.H.; Jørgensen, S. Occurrence, fate and effects of pharmaceutical substances in the environment- A review. Chemosphere 1998, 36, 357-393. [CrossRef]

6. Hernando, M.D.; Mezcua, M.; Alba, A.R.F.; Barceló, D. Environmental risk assessment of pharmaceutical residues in wastewater effluents, surface waters and sediments. Talanta 2006, 69, 334-342. [CrossRef] [PubMed]

7. Fent, K.; Weston, A.; Caminada, D. Ecotoxicology of human pharmaceuticals. Aquat. Toxicol. 2006, 76, 122-159. [CrossRef]

8. Nikolaou, A.; Meric, S.; Fatta, D. Occurrence patterns of pharmaceuticals in water and wastewater environments. Anal. Bioanal. Chem. 2007, 387, 1225-1234. [CrossRef] [PubMed] 
9. Schafhauser, B.H.; Kristofco, L.; de Oliveira, C.M.R.; Brooks, B.W. Global review and analysis of erythromycin in the environment: Occurrence, bioaccumulation and antibiotic resistance hazards. Environ. Pollut. 2018, 238, 440-451. [CrossRef]

10. Balakrishna, K.; Rath, A.; Praveenkumarreddy, Y.; Guruge, K.S.; Subedi, B. A review of the occurrence of pharmaceuticals and personal care products in Indian water bodies. Ecotoxicol. Environ. Saf. 2017, 137, 113-120. [CrossRef]

11. Der Beek, T.A.; Weber, F.-A.; Bergmann, A.; Hickmann, S.; Ebert, I.; Hein, A.; Küster, A. Pharmaceuticals in the environment-Global occurrences and perspectives. Environ. Toxicol. Chem. 2016, 35, 823-835. [CrossRef]

12. Heberer, T. Occurrence, fate, and removal of pharmaceutical residues in the aquatic environment: A review of recent research data. Toxicol. Lett. 2002, 131, 5-17. [CrossRef]

13. Heberer, T. Tracking persistent pharmaceutical residues from municipal sewage to drinking water. J. Hydrol. 2002, 266, 175-189. [CrossRef]

14. Larsson, D.J.; de Pedro, C.; Paxeus, N. Effluent from drug manufactures contains extremely high levels of pharmaceuticals. J. Hazard. Mater. 2007, 148, 751-755. [CrossRef] [PubMed]

15. Castiglioni, S.; Bagnati, R.; Fanelli, R.; Pomati, F.; Calamari, D.; Zuccato, E. Removal of Pharmaceuticals in Sewage Treatment Plants in Italy. Environ. Sci. Technol. 2006, 40, 357-363. [CrossRef] [PubMed]

16. Tixier, C.; Singer, H.P.; Oellers, S.; Müller, S.R. Occurrence and Fate of Carbamazepine, Clofibric Acid, Diclofenac, Ibuprofen, Ketoprofen, and Naproxen in Surface Waters. Environ. Sci. Technol. 2003, 37, 1061-1068. [CrossRef]

17. Ternes, T.A.; Meisenheimer, M.; McDowell, D.; Sacher, F.; Brauch, H.-J.; Haist-Gulde, B.; Preuss, G.; Wilme, U.; Zulei-Seibert, N Removal of Pharmaceuticals during Drinking Water Treatment. Environ. Sci. Technol. 2002, 36, 3855-3863. [CrossRef] [PubMed]

18. Westerhoff, P.; Yoon, Y.; Snyder, S.; Wert, E. Fate of Endocrine-Disruptor, Pharmaceutical, and Personal Care Product Chemicals during Simulated Drinking Water Treatment Processes. Environ. Sci. Technol. 2005, 39, 6649-6663. [CrossRef]

19. Daughton, C.G.; Ternes, T.A. Pharmaceuticals and personal care products in the environment: Agents of subtle change? Environ Health Perspect. 1999, 107, 907-938. [CrossRef] [PubMed]

20. Benotti, M.J.; Trenholm, R.A.; Vanderford, B.J.; Holady, J.C.; Stanford, B.D.; Snyder, S. Pharmaceuticals and Endocrine Disrupting Compounds in U.S. Drinking Water. Environ. Sci. Technol. 2009, 43, 597-603. [CrossRef] [PubMed]

21. Mhuka, V.; Dube, S.; Nindi, M.M. Occurrence of pharmaceutical and personal care products (PPCPs) in wastewater and receiving waters in South Africa using LC-OrbitrapTM MS. Emerg. Contam. 2020, 6, 250-258. [CrossRef]

22. WHO. WHO Model Lists of Essential Medicines; WHO: Geneva, Switzerland, 2020.

23. Yang, S.; Carlson, K. Evolution of antibiotic occurrence in a river through pristine, urban and agricultural landscapes. Water Res. 2003, 37, 4645-4656. [CrossRef]

24. Kulkarni, P.; Olson, N.D.; Raspanti, G.A.; Goldstein, R.E.R.; Gibbs, S.G.; Sapkota, A.; Sapkota, A.R. Antibiotic Concentrations Decrease during Wastewater Treatment but Persist at Low Levels in Reclaimed Water. Int. J. Environ. Res. Public Health 2017, 14, 668. [CrossRef]

25. Cai, M.-Q.; Wang, R.; Feng, L.; Zhang, L.-Q. Determination of selected pharmaceuticals in tap water and drinking water treatment plant by high-performance liquid chromatography-triple quadrupole mass spectrometer in Beijing, China. Environ. Sci. Pollut. Res. 2015, 22, 1854-1867. [CrossRef] [PubMed]

26. Tran, N.H.; Urase, T.; Ta, T.T. A Preliminary Study on the Occurrence of Pharmaceutically Active Compounds in Hospital Wastewater and Surface Water in Hanoi, Vietnam. CLEAN Soil Air Water 2014, 42, 267-275. [CrossRef]

27. Paíga, P.; Santos, L.; Ramos, S.; Jorge, S.; Silva, J.G.; Delerue-Matos, C. Presence of pharmaceuticals in the Lis river (Portugal): Sources, fate and seasonal variation. Sci. Total. Environ. 2016, 573, 164-177. [CrossRef]

28. Lolić, A.; Paíga, P.; Santos, L.H.; Ramos, S.; Correia, M.; Delerue-Matos, C. Assessment of non-steroidal anti-inflammatory and analgesic pharmaceuticals in seawaters of North of Portugal: Occurrence and environmental risk. Sci. Total. Environ. 2015, 508, 240-250. [CrossRef] [PubMed]

29. Petrovic, M.; Skrbic, B.; Živančev, J.; Climent, L.F.; Barceló, D. Determination of 81 pharmaceutical drugs by high performance liquid chromatography coupled to mass spectrometry with hybrid triple quadrupole-linear ion trap in different types of water in Serbia. Sci. Total. Environ. 2014, 468-469, 415-428. [CrossRef]

30. Santos, L.; Gros, M.; Rodriguez-Mozaz, S.; Delerue-Matos, C.; Pena, A.; Barceló, D.; Montenegro, M. Contribution of hospital effluents to the load of pharmaceuticals in urban wastewaters: Identification of ecologically relevant pharmaceuticals. Sci. Total. Environ. 2013, 461-462, 302-316. [CrossRef] [PubMed]

31. Kallenborn, R.; Fick, J.; Lindberg, R.; Moe, M.; Nielsen, K.M.; Tysklind, M.; Vasskog, T. Pharmaceutical Residues in Northern European Environments: Consequences and Perspectives. In Pharmaceuticals in the Environment; Springer: Berlin/Heidelberg, Germany, 2008; pp. 61-74.

32. Khetan, S.K.; Collins, T.J. Human pharmaceuticals in the aquatic environment: A challenge to green chemisty. Chem. Rev. 2007, 107, 2319-2364. [CrossRef] [PubMed]

33. Löffler, D.; Römbke, J.; Meller, M.; Ternes, T.A. Environmental Fate of Pharmaceuticals in Water/Sediment Systems. Environ. Sci. Technol. 2005, 39, 5209-5218. [CrossRef]

34. Li, W. Occurrence, sources, and fate of pharmaceuticals in aquatic environment and soil. Environ. Pollut. 2014, 187, 193-201. [CrossRef]

35. Lapworth, D.; Baran, N.; Stuart, M.; Ward, R. Emerging organic contaminants in groundwater: A review of sources, fate and occurrence. Environ. Pollut. 2012, 163, 287-303. [CrossRef] 
36. Pal, A.; Gin, K.Y.-H.; Lin, A.; Reinhard, M. Impacts of emerging organic contaminants on freshwater resources: Review of recent occurrences, sources, fate and effects. Sci. Total. Environ. 2010, 408, 6062-6069. [CrossRef] [PubMed]

37. Mompelat, S.; Le Bot, B.; Thomas, O. Occurrence and fate of pharmaceutical products and by-products, from resource to drinking water. Environ. Int. 2009, 35, 803-814. [CrossRef] [PubMed]

38. Joss, A.; Keller, E.; Alder, A.C.; Göbel, A.; McArdell, C.S.; Ternes, T.; Siegrist, H. Removal of pharmaceuticals and fragrances in biological wastewater treatment. Water Res. 2005, 39, 3139-3152. [CrossRef] [PubMed]

39. Jelic, A.; Gros, M.; Ginebreda, A.; Cespedes-Sánchez, R.; Ventura, F.; Petrovic, M.; Barceló, D. Occurrence, partition and removal of pharmaceuticals in sewage water and sludge during wastewater treatment. Water Res. 2011, 45, 1165-1176. [CrossRef] [PubMed]

40. Jjemba, P.K. Excretion and ecotoxicity of pharmaceutical and personal care products in the environment. Ecotoxicol. Environ. Saf. 2006, 63, 113-130. [CrossRef]

41. Ternes, T.A. Occurrence of drugs in German sewage treatment plants and rivers. Water Res. 1998, 32, 3245-3260. [CrossRef]

42. Bound, J.P.; Voulvoulis, N. Household Disposal of Pharmaceuticals as a Pathway for Aquatic Contamination in the United Kingdom. Environ. Health Perspect. 2005, 113, 1705-1711. [CrossRef] [PubMed]

43. Carlsson, C.; Johansson, A.K.; Alvan, G.; Bergman, K.; Kühler, T. Are pharmaceuticals potent environmental pollutants?: Part I: Environmental risk assessments of selected active pharmaceutical ingredients. Sci. Total Environ. 2006, 364, 67-87. [CrossRef] [PubMed]

44. Hirsch, R.; Ternes, T.; Haberer, K.; Kratz, K.-L. Occurrence of antibiotics in the aquatic environment. Sci. Total. Environ. 1999, 225, 109-118. [CrossRef]

45. Costanzo, S.D.; Murby, J.; Bates, J. Ecosystem response to antibiotics entering the aquatic environment. Mar. Pollut. Bull. 2005, 51, 218-223. [CrossRef] [PubMed]

46. Huschek, G.; Hansen, P.D.; Maurer, H.H.; Krengel, D.; Kayser, A. Environmental risk assesssment of medicinal products for human use according to European Commission recommendations. Environ. Toxicol. 2004, 19, 226-240. [CrossRef] [PubMed]

47. Petrie, B.; Barden, R.; Kasprzyk-Hordern, B. A review on emerging contaminants in wastewaters and the environment: Current knowledge, understudied areas and recommendations for future monitoring. Water Res. 2015, 72, 3-27. [CrossRef] [PubMed]

48. Oaks, J.L.; Gilbert, M.; Virani, M.Z.; Watson, R.T.; Meteyer, C.U.; Rideout, B.A.; Shivaprasad, H.L.; Ahmed, S.; Chaudhry, M.J.I.; Arshad, M.; et al. Diclofenac residues as the cause of vulture population decline in Pakistan. Nature 2004, 427, 630-633. [CrossRef]

49. Schwaiger, J.; Ferling, H.; Mallow, U.; Wintermayr, H.; Negele, R. Toxic effects of the non-steroidal anti-inflammatory drug diclofenac: Part I: Histopathological alterations and bioaccumulation in rainbow trout. Aquat. Toxicol. 2004, 68, 141-150. [CrossRef]

50. Triebskorn, R.; Casper, H.; Scheil, V.; Schwaiger, J. Ultrastructural effects of pharmaceuticals (carbamazepine, clofibric acid, metoprolol, diclofenac) in rainbow trout (Oncorhynchus mykiss) and common carp (Cyprinus carpio). Anal. Bioanal. Chem. 2007, 387, 1405-1416. [CrossRef]

51. Liu, F.; Ying, G.-G.; Tao, R.; Zhao, J.-L.; Yang, J.-F.; Zhao, L.-F. Effects of six selected antibiotics on plant growth and soil microbial and enzymatic activities. Environ. Pollut. 2009, 157, 1636-1642. [CrossRef]

52. Coelho, A.D.; Sans, C.; Agüera, A.; Gómez, M.J.; Esplugas, S.; Dezotti, M. Effects of ozone pre-treatment on diclofenac: Intermediates, biodegradability and toxicity assessment. Sci. Total. Environ. 2009, 407, 3572-3578. [CrossRef]

53. Gebhardt, W.; Schröder, H.F. Liquid chromatography-(tandem) mass spectrometry for the follow-up of the elimination of persistent pharmaceuticals during wastewater treatment applying biological wastewater treatment and advanced oxidation. J. Chromatogr. A 2007, 1160, 34-43. [CrossRef] [PubMed]

54. Suarez, S.; Lema, J.; Omil, F. Pre-treatment of hospital wastewater by coagulation-flocculation and flotation. Bioresour. Technol. 2009, 100, 2138-2146. [CrossRef]

55. Bui, T.X.; Choi, H. Adsorptive removal of selected pharmaceuticals by mesoporous silica SBA-15. J. Hazard. Mater. 2009, 168, 602-608. [CrossRef] [PubMed]

56. Al-Ghouti, M.A.; Khraisheh, M.A.; Ahmad, M.N.; Allen, S. Adsorption behaviour of methylene blue onto Jordanian diatomite: A kinetic study. J. Hazard. Mater. 2009, 165, 589-598. [CrossRef] [PubMed]

57. Brown, P.A.; Brown, J.M.; Allen, S.J. The application of kudzu as a medium for the adsorption of heavy metals from dilute aqueous wastestreams. Bioresour. Technol. 2001, 78, 195-201. [CrossRef]

58. Homem, V.; Santos, L. Degradation and removal methods of antibiotics from aqueous matrices-A review. J. Environ. Manag. 2011, 92, 2304-2347. [CrossRef]

59. El Qada, E.N.; Allen, S.J.; Walker, G.M. Adsorption of basic dyes from aqueous solution onto activated carbons. Chem. Eng. J. 2008, 135, 174-184. [CrossRef]

60. El Qada, E.N.; Allen, S.J.; Walker, G. Adsorption of Methylene Blue onto activated carbon produced from steam activated bituminous coal: A study of equilibrium adsorption isotherm. Chem. Eng. J. 2006, 124, 103-110. [CrossRef]

61. Vieno, N.M.; Härkki, H.; Tuhkanen, T.; Kronberg, L. Occurrence of Pharmaceuticals in River Water and Their Elimination in a Pilot-Scale Drinking Water Treatment Plant. Environ. Sci. Technol. 2007, 41, 5077-5084. [CrossRef] [PubMed]

62. de Sousa, D.N.R.; Insa, S.; Mozeto, A.A.; Petrovic, M.; Chaves, T.F.; Fadini, P.S. Equilibrium and kinetic studies of the adsorption of antibiotics from aqueous solutions onto powdered zeolites. Chemosphere 2018, 205, 137-146. [CrossRef] [PubMed]

63. Masters, A.F.; Maschmeyer, T. Zeolites-From curiosity to cornerstone. Microporous Mesoporous Mater. 2011, 142, 423-438. [CrossRef] 
64. Valdés, M.G.; Pérez-Cordoves, A.; Díaz-García, M. Zeolites and zeolite-based materials in analytical chemistry. TrAC Trends Anal. Chem. 2006, 25, 24-30. [CrossRef]

65. Franus, W.; Wdowin, M.; Franus, M. Synthesis and characterization of zeolites prepared from industrial fly ash. Environ. Monit. Assess. 2014, 186, 5721-5729. [CrossRef]

66. Franus, M.; Wdowin, M.; Bandura, L.; Franus, W. Removal of environmental pollutions using zeolites from fly ash: A review. Fresenius Environ. Bull. 2015, 24, 854-866.

67. Niwa, M.; Katada, N.; Okumura, K. Introduction to Zeolite Science and Catalysis. In Superconductivity; Springer Science and Business Media LLC: Berlin/Heidelberg, Germany, 2010; Volume 141, pp. 1-8.

68. Li, Y.; Yu, J. New Stories of Zeolite Structures: Their Descriptions, Determinations, Predictions, and Evaluations. Chem. Rev. 2014, 114, 7268-7316. [CrossRef] [PubMed]

69. Weitkamp, J. Zeolites and catalysis. Solid State Ion. 2000, 131, 175-188. [CrossRef]

70. Burton, A. Recent trends in the synthesis of high-silica zeolites. Catal. Rev. 2018, 60, 132-175. [CrossRef]

71. Burton, A.W.; Zones, S.I.; Elomari, S. The chemistry of phase selectivity in the synthesis of high-silica zeolites. Curr. Opin. Colloid Interface Sci. 2005, 10, 211-219. [CrossRef]

72. Maesen, T. The zeolite scene-An overview. In Studies in Surface Science and Catalysis; Elsevier Inc.: Amsterdam, The Netherlands, 2007; Volume 168, pp. 1-12. ISBN 0444530630.

73. Baerlocher, C.; McCusker, L.B.; Olson, D.H. Atlas of Zeolite Framework Types, 6th ed.; Elsevier: Amsterdam, The Netherlands, 2007; Available online: https://www.elsevier.com/books/atlas-of-zeolite-framework-types/baerlocher/978-0-444-53064-6 (accessed on 24 September 2020).

74. Foster, M.; Rivin, I.; Treacy, M.; Friedrichs, O.D. A geometric solution to the largest-free-sphere problem in zeolite frameworks. Microporous Mesoporous Mater. 2006, 90, 32-38. [CrossRef]

75. Meier, W.M.; Baerlocher, C. Zeolite type frameworks: Connectivities, configurations and conformations. In Structures and Structure Determination; Springer: Berlin/Heidelberg, Germany, 1999; pp. 141-161.

76. Feng, S.-H.; Li, G.-H. Hydrothermal and Solvothermal Syntheses. In Modern Inorganic Synthetic Chemistry; Elsevier BV: Amsterdam, The Netherlands, 2017; pp. 73-104.

77. Wang, Y.U.J.; Jia, D.E.A.N.; Rui-Juan, S.U.N.; Hao-Wen, Z.H.U.; Zhou, D.M. Adsorption and cosorption of tetracycline and copper(ll) on montmorillonite as affected by solution pH. Environ. Sci. Technol. 2008, 42, 3254-3259. [CrossRef]

78. Miyake, M.; Tamura, C.; Matsuda, M. Resource Recovery of Waste Incineration Fly Ash: Synthesis of Zeolites A and P. J. Am. Ceram. Soc. 2004, 85, 1873-1875. [CrossRef]

79. Hui, K.S.; Chao, C. Effects of step-change of synthesis temperature on synthesis of zeolite 4A from coal fly ash. Microporous Mesoporous Mater. 2006, 88, 145-151. [CrossRef]

80. Tanaka, H.; Fujii, A. Effect of stirring on the dissolution of coal fly ash and synthesis of pure-form Na-A and -X zeolites by two-step process. Adv. Powder Technol. 2009, 20, 473-479. [CrossRef]

81. Nascimento, M.; Soares, P.S.M.; Souza, V.P. Adsorption of heavy metal cations using coal fly ash modified by hydrothermal method. Fuel 2009, 88, 1714-1719. [CrossRef]

82. Ma, W.; Brown, P.W.; Komarneni, S. Characterization and cation exchange properties of zeolite synthesized from fly ashes. J. Mater. Res. 1998, 13, 3-7. [CrossRef]

83. Steenbruggen, G.; Hollman, G. The synthesis of zeolites from fly ash and the properties of the zeolite products. J. Geochem. Explor. 1998, 62, 305-309. [CrossRef]

84. Park, M.; Choi, C.L.; Lim, W.T.; Kim, M.C.; Choi, J.; Heo, N.H. Molten-salt method for the synthesis of zeolitic materials: I. Zeolite formation in alkaline molten-salt system. Microporous Mesoporous Mater. 2000, 37, 81-89. [CrossRef]

85. Woolard, C.D.; Petrus, K.; van der Horst, M. The use of a modified fly ash as an adsorbent for lead. Water SA 2000, $26,531-536$.

86. Querol, X.; Moreno, N.; Umana, J.; Juan, R.; Hernandez, S.; Pereira, C.F.; Ayora, C.; Janssen, M.; Garcia-Martinez, J.; Linares-Solano, A.; et al. Application of zeolitic material synthesised from fly ash to the decontamination of waste water and flue gas. J. Chem. Technol. Biotechnol. 2002, 77, 292-298. [CrossRef]

87. Moreno, N.; Querol, X.; Plana, F.; Andres, J.M.; Janssen, M.; Nugteren, H. Pure zeolite synthesis from silica extracted from coal fly ashes. J. Chem. Technol. Biotechnol. 2002, 77, 274-279. [CrossRef]

88. Murayama, N.; Yamamoto, H.; Shibata, J. Mechanism of zeolite synthesis from coal fly ash by alkali hydrothermal reaction. Int. J. Miner. Process. 2002, 64, 1-17. [CrossRef]

89. Adamczyk, Z.; Bialecka, B. Hydrothermal synthesis of zeolites from Polish coal fly ash. Pol. J. Environ. Stud. 2005, 14, 713-719.

90. Derkowski, A.; Franus, W.; Beran, E.; Czímerová, A. Properties and potential applications of zeolitic materials produced from fly ash using simple method of synthesis. Powder Technol. 2006, 166, 47-54. [CrossRef]

91. Musyoka, N.M.; Petrik, L.F.; Balfour, G.; Gitari, W.M.; Hums, E. Synthesis of hydroxy sodalite from coal fly ash using waste industrial brine solution. J. Environ. Sci. Health Part A 2011, 46, 1699-1707. [CrossRef]

92. Srinivasan, A.; Grutzeck, M.W. The Adsorption of SO2by Zeolites Synthesized from Fly Ash. Environ. Sci. Technol. 1999, 33, 1464-1469. [CrossRef]

93. Sakthivel, T.; Reid, D.L.; Goldstein, I.; Hench, L.; Seal, S. Hydrophobic High Surface Area Zeolites Derived from Fly Ash for Oil Spill Remediation. Environ. Sci. Technol. 2013, 47, 5843-5850. [CrossRef] 
94. Bukhari, S.S.; Behin, J.; Kazemian, H.; Rohani, S. Conversion of coal fly ash to zeolite utilizing microwave and ultrasound energies: A review. Fuel 2015, 140, 250-266. [CrossRef]

95. Franus, W.; Wdowin, M. Wykorzystanie popiołów lotnych klasy F do produkcji materiału zeolitowego na skalę półtechniczną. Polityka Energ. 2011, 14, 79-91.

96. Cordoves, A.; Valdés, M.; Fernández, J.C.; Luis, G.; García-Calzón, J.; García, M.E. Characterization of the binding site affinity distribution of a surfactant-modified clinoptilolite. Microporous Mesoporous Mater. 2008, 109, 33-48. [CrossRef]

97. Jha, B.; Singh, D.N. ChemInform Abstract: A Review on Synthesis, Characterization and Industrial Applications of Flyash Zeolites. TrAC Trends Anal. Chem. 2012, 33, 65-132. [CrossRef]

98. Martucci, A.; Pasti, L.; Marchetti, N.; Cavazzini, A.; Dondi, F.; Alberti, A. Adsorption of pharmaceuticals from aqueous solutions on synthetic zeolites. Microporous Mesoporous Mater. 2012, 148, 174-183. [CrossRef]

99. de Ridder, D.; Verberk, J.; Heijman, B.; Amy, G.; van Dijk, J. Zeolites for nitrosamine and pharmaceutical removal from demineralised and surface water: Mechanisms and efficacy. Sep. Purif. Technol. 2012, 89, 71-77. [CrossRef]

100. Rouquerol, J.; Avnir, D.; Fairbridge, C.W.; Everett, D.H.; Haynes, J.M.; Pernicone, N.; Ramsay, J.D.F.; Sing, K.S.W.; Unger, K.K Recommendations for the characterization of porous solids (Technical Report). Pure Appl. Chem. 1994, 66, 1739-1758. [CrossRef]

101. Davis, M.E. Ordered porous materials for emerging applications. Nature 2002, 417, 813-821. [CrossRef] [PubMed]

102. Corma, A. From Microporous to Mesoporous Molecular Sieve Materials and Their Use in Catalysis. Chem. Rev. 1997, 97, 2373-2420. [CrossRef] [PubMed]

103. Zhao, D.; Feng, J.; Huo, Q.; Melosh, N.; Fredrickson, G.H.; Chmelka, B.F.; Stucky, G.D. Triblock Copolymer Syntheses of Mesoporous Silica with Periodic 50 to 300 Angstrom Pores. Science 1998, 279, 548-552. [CrossRef] [PubMed]

104. Zhao, D.; Huo, Q.; Feng, J.; Chmelka, B.F.; Stucky, G.D. Nonionic Triblock and Star Diblock Copolymer and Oligomeric Surfactant Syntheses of Highly Ordered, Hydrothermally Stable, Mesoporous Silica Structures. J. Am. Chem. Soc. 1998, 120, 6024-6036. [CrossRef]

105. Göltner, C.G.; Henke, S.; Weissenberger, M.C.; Antonietti, M. Mesoporous Silica from Lyotropic Liquid Crystal Polymer Templates. Angew. Chem. Int. Ed. 1998, 37, 613-616. [CrossRef]

106. Narayan, R.; Nayak, U.Y.; Raichur, A.M.; Garg, S. Mesoporous Silica Nanoparticles: A Comprehensive Review on Synthesis and Recent Advances. Pharmaceutics 2018, 10, 118. [CrossRef]

107. Schwanke, A.J.; Balzer, R.; Pergher, S. Microporous and mesoporous materials from natural and inexpensive sources. In Handbook of Ecomaterials; Springer International Publishing: Berlin/Heidelberg, Germany, 2019; Volume 5, pp. 3379-3399. ISBN 9783319682556.

108. Huo, Q.; Margolese, D.I.; Ciesla, U.; Feng, P.; Gier, T.E.; Sieger, P.; Leon, R.; Petroff, P.M.; Schüth, F.; Stucky, G.D. Generalized synthesis of periodic surfactant/inorganic composite materials. Nature 1994, 368, 317-321. [CrossRef]

109. Jin, Z.; Wang, X.; Cui, X. A two-step route to synthesis of small-pored and thick-walled SBA-16-type mesoporous silica under mildly acidic conditions. J. Colloid Interface Sci. 2007, 307, 158-165. [CrossRef] [PubMed]

110. Li, D.; Guan, X.; Song, J.; Di, Y.; Zhang, D.; Ge, X.; Zhao, L.; Xiao, F.-S. Highly efficient synthesis of ordered mesoporous silica materials with controllable microporosity using surfactant mixtures as templates. Colloids Surf. A Physicochem. Eng. Asp. 2006, 272, 194-202. [CrossRef]

111. Hoffmann, F.; Cornelius, M.; Morell, J.; Fröba, M. Silica-Based Mesoporous Organic-Inorganic Hybrid Materials. Angew. Chem. Int. Ed. 2006, 45, 3216-3251. [CrossRef]

112. Gao, P.; Liang, Z.; Zhao, Z.; Wang, W.; Yang, C.; Hu, B.; Cui, F. Enhanced adsorption of steroid estrogens by one-pot synthesized phenyl-modified mesoporous silica: Dependence on phenyl-organosilane precursors and pH condition. Chemosphere 2019, 234, 438-449. [CrossRef] [PubMed]

113. Li, H.; Li, Y.; Zhang, Z.; Pang, X.; Yu, X. Highly selective luminescent sensing of Cu2+ in aqueous solution based on a Eu(III)centered periodic mesoporous organosilicas hybrid. Mater. Des. 2019, 172, 107712. [CrossRef]

114. Luoa, G.; Li, Y.; Wang, A.; Lin, Q.; Zhang, G.; Wang, C. Dummy molecularly imprinted mesoporous silicates for selective adsorption of 2-naphthol. Open Chem. 2015, 13, 756-762. [CrossRef]

115. Miao, Y.; Sun, X.; Lv, J.; Yan, G. -Phosphorescent Mesoporous Surface Imprinting Microspheres: Preparation and Application for Transferrin Recognition from Biological Fluids. ACS Appl. Mater. Interfaces 2018, 11, 2264-2272. [CrossRef]

116. Grassi, M.; Kaykioglu, G.; Belgiorno, V.; Lofrano, G. Removal of Emerging Contaminants from Water and Wastewater by Adsorption Process; Springer: Dordrecht, The Netherlands, 2012; pp. 15-37.

117. Banerjee, S.; Barman, S.; Halder, G. Sorptive elucidation of rice husk ash derived synthetic zeolite towards deionization of coalmine waste water: A comparative study. Groundw. Sustain. Dev. 2017, 5, 137-151. [CrossRef]

118. Chakraborty, P.; Show, S.; Banerjee, S.; Halder, G. Mechanistic insight into sorptive elimination of ibuprofen employing bidirectional activated biochar from sugarcane bagasse: Performance evaluation and cost estimation. J. Environ. Chem. Eng. 2018, 6, 5287-5300. [CrossRef]

119. Durán, A.; Monteagudo, J.M.; Martínez, J.M.M. Operation costs of the solar photo-catalytic degradation of pharmaceuticals in water: A mini-review. Chemosphere 2018, 211, 482-488. [CrossRef]

120. Ahmed, M.B.; Zhou, J.L.; Ngo, H.H.; Guo, W. Adsorptive removal of antibiotics from water and wastewater: Progress and challenges. Sci. Total. Environ. 2015, 532, 112-126. [CrossRef] [PubMed]

121. Ali, I. Water Treatment by Adsorption Columns: Evaluation at Ground Level. Sep. Purif. Rev. 2013, 43, 175-205. [CrossRef] 
122. Monteil, H.; Péchaud, Y.; Oturan, N.; Oturan, M.A. A review on efficiency and cost effectiveness of electro- and bio-electro-Fenton processes: Application to the treatment of pharmaceutical pollutants in water. Chem. Eng. J. 2019, 376, 119577. [CrossRef]

123. Wood, T.P.; Du Preez, C.; Steenkamp, A.; Duvenage, C.; Rohwer, E.R. Database-driven screening of South African surface water and the targeted detection of pharmaceuticals using liquid chromatography-High resolution mass spectrometry. Environ. Pollut. 2017, 230, 453-462. [CrossRef] [PubMed]

124. Richardson, S.D.; Ternes, T.A. Water Analysis: Emerging Contaminants and Current Issues. Anal. Chem. 2018, 90, 398-428. [CrossRef] [PubMed]

125. Veras, T.B.; de Paiva, A.L.R.; Duarte, M.M.M.B.; Napoleão, D.C.; Cabral, J.J.D.S.P. Analysis of the presence of anti-inflammatories drugs in surface water: A case study in Beberibe river-PE, Brazil. Chemosphere 2019, 222, 961-969. [CrossRef]

126. Tramèr, M.R.; Moore, R.A.; Reynolds, D.J.M.; McQuay, H.J. Quantitative estimation of rare adverse events which follow a biological progression: A new model applied to chronic NSAID use. Pain 2000, 85, 169-182. [CrossRef]

127. Caracciolo, A.B.; Topp, E.; Grenni, P. Pharmaceuticals in the environment: Biodegradation and effects on natural microbial communities. A review. J. Pharm. Biomed. Anal. 2015, 106, 25-36. [CrossRef] [PubMed]

128. Chaiamnuay, S.; Allison, J.J.; Curtis, J.R. Risks versus benefits of cyclooxygenase-2-selective nonsteroidal antiinflammatory drugs. Am. J. Health Pharm. 2006, 63, 1837-1851. [CrossRef] [PubMed]

129. Vane, J.; Botting, R. The mechanism of action of aspirin. Thromb. Res. 2003, 110, 255-258. [CrossRef]

130. Brzozowski, T.; Konturek, P.C.; Konturek, S.J.; Sliwowski, Z.; Pajdo, R.; Drozdowicz, D.; Ptak, A.; Hahn, E.G. Classic NSAID and selective cyclooxygenase (COX)-1 and COX-2 inhibitors in healing of chronic gastric ulcers. Microsc. Res. Tech. 2001, 53, 343-353. [CrossRef]

131. Celiz, M.D.; Tso, J.; Aga, D.S. Pharmaceutical Metabolites in The Environment: Analytical Challenges And Ecological Risks. Environ. Toxicol. Chem. 2009, 28, 2473-2484. [CrossRef]

132. Lienert, J.; Güdel, K.; Escher, B.I. Screening Method for Ecotoxicological Hazard Assessment of 42 Pharmaceuticals Considering Human Metabolism and Excretory Routes. Environ. Sci. Technol. 2007, 41, 4471-4478. [CrossRef]

133. Davies, N.M.; Andersen, K.E. Clinical pharmacokinetics of diclofenac. Therapeutic insights and pitfalls. Clin. Pharmacokinet. 1997, 33, 184-213. [CrossRef] [PubMed]

134. Rainsford, K.D. Ibuprofen: Pharmacology, efficacy and safety. Inflammopharmacology 2009, 17, 275-342. [CrossRef]

135. Bushra, R.; Aslam, N. An Overview of Clinical Pharmacology of Ibuprofen. Oman Med. J. 2010, 25, 155-161. [CrossRef]

136. Gaskell, H.; Derry, S.; Wiffen, P.J.; Moore, R.A. Single dose oral ketoprofen or dexketoprofen for acute postoperative pain in adults. Cochrane Database Syst. Rev. 2017, 5, CD007355. [CrossRef]

137. Brogden, R.N.; Heel, R.C.; Speight, T.M.; Avery, G.S. Naproxen up to Date: A Review of its Pharmacological Properties and Therapeutic Efficacy and Use in Rheumatic Diseases and Pain States. Drugs 1979, 18, 241-277. [CrossRef]

138. Bowalgaha, K.; Elliot, D.J.; MacKenzie, P.I.; Knights, K.M.; Swedmark, S.; Miners, J.O. S-Naproxen and desmethylnaproxen glucuronidation by human liver microsomes and recombinant human UDP-glucuronosyltransferases (UGT): Role of UGT2B7 in the elimination of naproxen. Br. J. Clin. Pharmacol. 2005, 60, 423-433. [CrossRef]

139. Colburn, W.A.; Di Santo, A.R.; Gibaldi, M. Pharmacokinetics of Erythromycin on Repetitive Dosing. J. Clin. Pharmacol. 1977, 17, 592-600. [CrossRef]

140. Fohner, A.E.; Sparreboom, A.; Altman, R.B.; Klein, T.E. PharmGKB summary: Macrolide antibiotic pathway, pharmacokinetics/pharmacodynamics. Pharmacogenet. Genom. 2017, 27, 164-167. [CrossRef] [PubMed]

141. Van Der Ven, A.J.; Mantel, M.A.; Vree, T.B.; Koopmans, P.P.; Van Der Meer, J.W. Formation and elimination of sulphamethoxazole hydroxylamine after oral administration of sulphamethoxazole. Br. J. Clin. Pharmacol. 1994, 38, 147-150. [CrossRef]

142. Michałek, K.; Lechowicz, M.; Pastuszczak, M.; Wojas-Pelc, A. The use of trimethoprim and sulfamethoxazole (TMP-SMX) in dermatology. Folia Med. Crac. 2015, 55, 35-41.

143. Griffin, M.O.; Fricovsky, E.; Ceballos, G.; Villarreal, F. Tetracyclines: A pleitropic family of compounds with promising therapeutic properties. Review of the literature. Am. J. Physiol. Physiol. 2010, 299, C539-C548. [CrossRef] [PubMed]

144. Goldman, J.L.; Leeder, J.S.E.; Van Haandel, L.; Pearce, R.E. In Vitro Hepatic Oxidative Biotransformation of Trimethoprim. Drug Metab. Dispos. 2015, 43, 1372-1380. [CrossRef]

145. America, N.I. of H. (NIH): U.S. of PubChem. Available online: https://pubchem.ncbi.nlm.nih.gov/ (accessed on 25 September 2020).

146. Ling, Y.; Klemes, M.J.; Xiao, L.; Alsbaiee, A.; Dichtel, W.R.; Helbling, D.E. Benchmarking Micropollutant Removal by Activated Carbon and Porous $\beta$-Cyclodextrin Polymers under Environmentally Relevant Scenarios. Environ. Sci. Technol. 2017, 51, 7590-7598. [CrossRef]

147. Fick, J.; Lindberg, R.H.; Tysklind, M.; Larsson, D.J. Predicted critical environmental concentrations for 500 pharmaceuticals. Regul. Toxicol. Pharmacol. 2010, 58, 516-523. [CrossRef]

148. Schmidt, S.; Hoffmann, H.; Garbe, L.-A.; Schneider, R.J. Liquid chromatography-tandem mass spectrometry detection of diclofenac and related compounds in water samples. J. Chromatogr. A 2018, 1538, 112-116. [CrossRef]

149. Vanderford, B.J.; Snyder, S. Analysis of Pharmaceuticals in Water by Isotope Dilution Liquid Chromatography/Tandem Mass Spectrometry. Environ. Sci. Technol. 2006, 40, 7312-7320. [CrossRef] [PubMed] 
150. Palli, L.; Spina, F.; Varese, G.C.; Vincenzi, M.; Aragno, M.; Arcangeli, G.; Mucci, N.; Santianni, D.; Caffaz, S.; Gori, R. Occurrence of selected pharmaceuticals in wastewater treatment plants of Tuscany: An effect-based approach to evaluate the potential environmental impact. Int. J. Hyg. Environ. Health 2019, 222, 717-725. [CrossRef]

151. Guedes-Alonso, R.; Montesdeoca-Esponda, S.; Pacheco-Juárez, J.; Sosa-Ferrera, Z.; Santana-Rodríguez, J.J. A Survey of the Presence of Pharmaceutical Residues in Wastewaters. Evaluation of Their Removal using Conventional and Natural Treatment Procedures. Molecules 2020, 25, 1639. [CrossRef]

152. Landová, P.; Vávrová, M. A new method for macrolide antibiotics determination in wastewater from three different wastewater treatment plants. Acta Chim. Slovaca 2017, 10, 47-53. [CrossRef]

153. Semreen, M.H.; Shanableh, A.; Semerjian, L.; Alniss, H.; Mousa, M.; Bai, X.; Acharya, K. Simultaneous Determination of Pharmaceuticals by Solid-phase Extraction and Liquid Chromatography-Tandem Mass Spectrometry: A Case Study from Sharjah Sewage Treatment Plant. Molecules 2019, 24, 633. [CrossRef] [PubMed]

154. Jank, L.; Hoff, R.; Da Costa, F.J.; Pizzolato, T.M. Simultaneous determination of eight antibiotics from distinct classes in surface and wastewater samples by solid-phase extraction and high-performance liquid chromatography-electrospray ionisation mass spectrometry. Int. J. Environ. Anal. Chem. 2014, 94, 1013-1037. [CrossRef]

155. Opris, O.; Soran, M.-L.; Coman, V.; Copaciu, F.; Ristoiu, D. Determination of some frequently used antibiotics in waste waters using solid phase extraction followed by high performance liquid chromatography with diode array and mass spectrometry detection. Open Chem. 2013, 11, 1343-1351. [CrossRef]

156. Kim, C.; Ryu, H.-D.; Chung, E.G.; Kim, Y. Determination of 18 veterinary antibiotics in environmental water using highperformance liquid chromatography-q-orbitrap combined with on-line solid-phase extraction. J. Chromatogr. B 2018, 1084, 158-165. [CrossRef] [PubMed]

157. Rac, V.; Rakić, V.; Stošić, D.; Pavlović, V.; Bosnar, S.; Auroux, A. Enhanced accessibility of active sites in hierarchical ZSM-5 zeolite for removal of pharmaceutically active substances: Adsorption and microcalorimetric study. Arab. J. Chem. 2020, 13, 1945-1954. [CrossRef]

158. Attia, T.M.S.; Hu, X.; Yin, D.Q. Synthesized magnetic nanoparticles coated zeolite for the adsorption of pharmaceutical compounds from aqueous solution using batch and column studies. Chemosphere 2013, 93, 2076-2085. [CrossRef] [PubMed]

159. Al-Rimawi, F.; Daana, M.; Khamis, M.; Karaman, R.; Khoury, H.; Qurie, M. Removal of Selected Pharmaceuticals from Aqueous Solutions Using Natural Jordanian Zeolite. Arab. J. Sci. Eng. 2019, 44, 209-215. [CrossRef]

160. Kuwahara, Y.; Aoyama, J.; Miyakubo, K.; Eguchi, T.; Kamegawa, T.; Mori, K.; Yamashita, H. TiO 2 photocatalyst for degradation of organic compounds in water and air supported on highly hydrophobic FAU zeolite: Structural, sorptive, and photocatalytic studies. J. Catal. 2012, 285, 223-234. [CrossRef]

161. Duke, M.C.; O’Brien-Abraham, J.; Milne, N.; Zhu, B.; Lin, J.Y.; da Costa, J.C.D. Seawater desalination performance of MFI type membranes made by secondary growth. Sep. Purif. Technol. 2009, 68, 343-350. [CrossRef]

162. An, Y.; De Ridder, D.J.; Zhao, C.; Schoutteten, K.; Bussche, J.V.; Zheng, H.; Chen, G.; Vanhaecke, L. Adsorption and photocatalytic degradation of pharmaceuticals and pesticides by carbon doped-TiO2 coated on zeolites under solar light irradiation. Water Sci. Technol. 2016, 73, 2868-2881. [CrossRef]

163. Attia, T.M.S.; Hu, X.; Yin, D.Q. Synthesised magnetic nanoparticles coated zeolite (MNCZ) for the removal of arsenic (As) from aqueous solution. J. Exp. Nanosci. 2012, 9, 551-560. [CrossRef]

164. Szabová, P.; Plekancová, M.; Gróf, N.; Bodík, I. Slovak natural zeolites as a suitable medium for antibiotics elimination from wastewater. Acta Chim. Slovaca 2019, 12, 163-167. [CrossRef]

165. Blasioli, S.; Martucci, A.; Paul, G.; Gigli, L.; Cossi, M.; Johnston, C.T.; Marchese, L.; Braschi, I. Removal of sulfamethoxazole sulfonamide antibiotic from water by high silica zeolites: A study of the involved host-guest interactions by a combined structural, spectroscopic, and computational approach. J. Colloid Interface Sci. 2014, 419, 148-159. [CrossRef]

166. Braschi, I.; Martucci, A.; Blasioli, S.; Mzini, L.L.; Ciavatta, C.; Cossi, M. Effect of humic monomers on the adsorption of sulfamethoxazole sulfonamide antibiotic into a high silica zeolite Y: An interdisciplinary study. Chemosphere 2016, 155, 444-452. [CrossRef]

167. Wang, C.-F.; Li, J.-S.; Wang, L.-J.; Sun, X.-Y. Influence of $\mathrm{NaOH}$ concentrations on synthesis of pure-form zeolite A from fly ash using two-stage method. J. Hazard. Mater. 2008, 155, 58-64. [CrossRef]

168. Suriyanon, N.; Punyapalakul, P.; Ngamcharussrivichai, C. Mechanistic study of diclofenac and carbamazepine adsorption on functionalized silica-based porous materials. Chem. Eng. J. 2013, 214, 208-218. [CrossRef]

169. Bui, T.X.; Pham, V.H.; Le, S.T.; Choi, H. Adsorption of pharmaceuticals onto trimethylsilylated mesoporous SBA-15. J. Hazard. Mater. 2013, 254-255, 345-353. [CrossRef]

170. Liu, M.; Hou, L.-A.; Yu, S.; Xi, B.; Zhao, Y.; Xia, X. MCM-41 impregnated with A zeolite precursor: Synthesis, characterization and tetracycline antibiotics removal from aqueous solution. Chem. Eng. J. 2013, 223, 678-687. [CrossRef]

171. Daughton, C.G. Non-regulated water contaminants: Emerging research. Environ. Impact Assess. Rev. 2004, 24, 711-732. [CrossRef]

172. Kolpin, D.W.; Furlong, E.; Meyer, M.; Thurman, E.M.; Zaugg, S.D.; Barber, L.B.; Buxton, H.T. Pharmaceuticals, Hormones, and Other Organic Wastewater Contaminants in U.S. Streams, 1999-2000: A National Reconnaissance. Environ. Sci. Technol. 2002, 36, 1202-1211. [CrossRef] [PubMed]

173. Sorensen, J.; Lapworth, D.; Nkhuwa, D.; Stuart, M.; Gooddy, D.; Bell, R.; Chirwa, M.; Kabika, J.; Liemisa, M.; Chibesa, M.; et al. Emerging contaminants in urban groundwater sources in Africa. Water Res. 2015, 72, 51-63. [CrossRef] 